\title{
Three Seasons of Archaeological Survey in the Aru Islands, 1995-97
}

\author{
Matthew Spriggs ${ }^{1}$, Peter Veth², Sue 0'Connor ${ }^{1}$, Husni Mohammad³, Ako Jatmiko4, \\ Widya Nayati ${ }^{5}$, Aliza Diniasti Saleh4, and Djoko Witjaksono ${ }^{6}$ \\ 1. Archaeology and Natural History, Research School of Pacific and Asian Studies, \\ The Australian National University, Canberra, ACT, Australia \\ 2. Research Unit, Australian Institute of Aboriginal and Torres Strait Islander Studies, Canberra, ACT, Australia \\ 3. Puslit Arkenas, Branch Menado, Indonesia \\ 4. Puslit Arkenas, Jakarta, Indonesia \\ 5. Department of Archaeology, Gajah Mada University, Yogyakarta, Indonesia \\ 6. Museum Negeri Ronggowarsito, Jalan Abdulrahman Saleh, Semarang, Central Java, Indonesia
}

\section{Introduction}

Armed with the set of questions and issues discussed in Chapter 1, we arrived in Aru in 1995 and began a reconnaissance survey, which was continued in a more targeted way in 1996 and 1997. In each year, a considerable amount of time was spent liaising with kepala desa (village leaders, Bahasa Indonesian) and communities, towards a thorough explanation of our objectives and in order to identify any known sites. After travelling to the various islands from the kecamatan (district capital), Dobo, the general strategy was to carry out formal discussions and interviews, address adat (customary law) issues, and then carry out surveys and site inspections with community representatives.

Initial reconnaissance surveys in 1995 were focussed on the northwest islands as these lay closest to the edge of the Continental Shelf. As discussed in Chapter 1, we had hoped they might provide stratified sites with old and continuous occupation sequences, perhaps going back to the earliest period of human occupation of Aru. These islands comprised Kobroor, Wamar, Wokam, Ujir and Wasir (Fig. 4.1). Most of the geological formations surveyed on these islands were found to be unsuitable for cave or rockshelter formation. Where caves were found, they were either posttransgression sea caves of recent origin in soft sedimentary rock or contained running water and thus were unsuitable for human occupation. Our initial strategy to target cave sites on the northwestern islands closest to the edge of the Continental Shelf, in the hope of finding evidence of Pleistocene occupation, thus proved unsuccessful.

Suitable caves in this part of Aru appear to be restricted to the karst formations, which mainly occur in the interior of the larger islands and are away from early shorelines. In 1995 only one cave with clear excavation potential was located. This was Liang Lemdubu (Site 9), the focus 


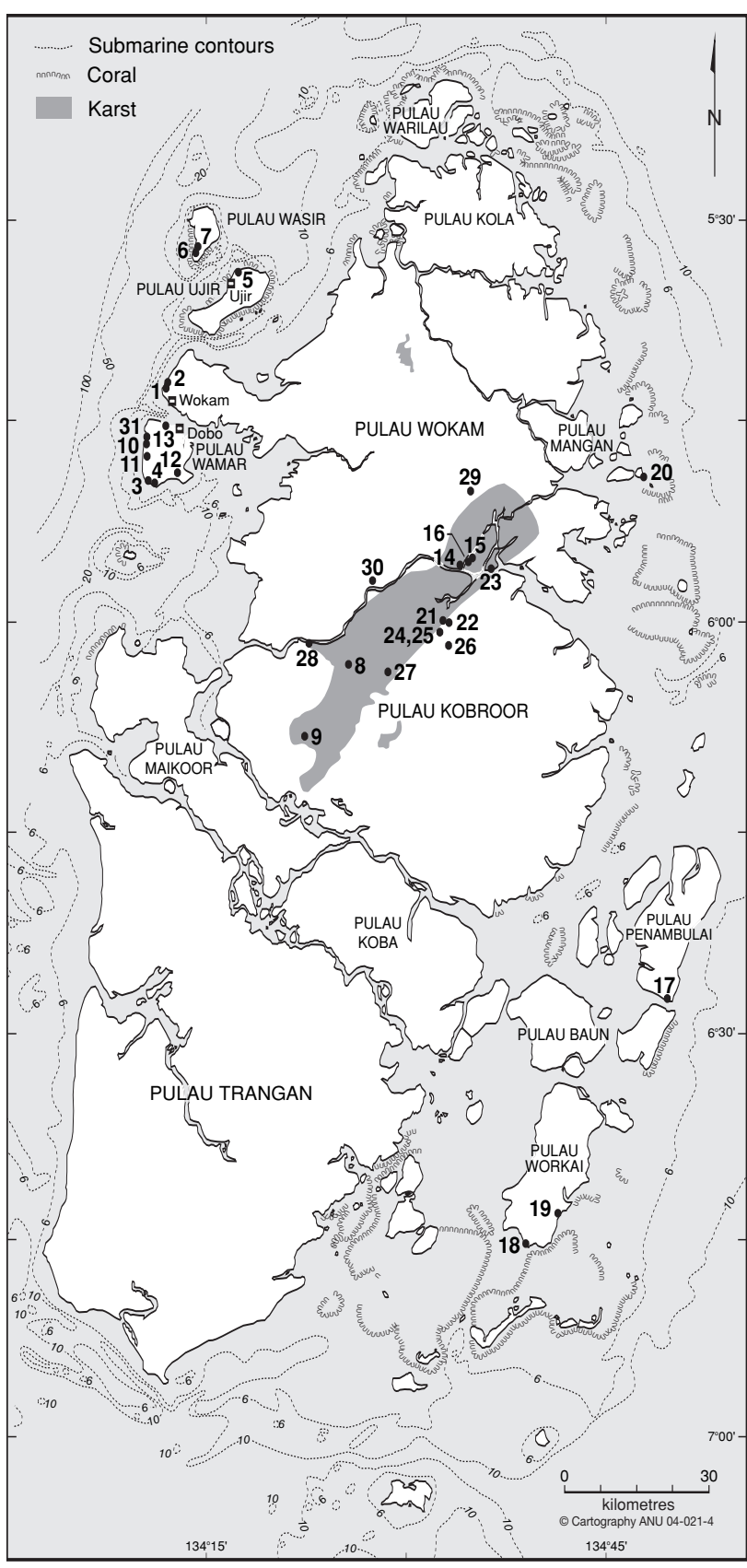

Figure 4.1 Map of the Aru Islands showing the location of all sites mentioned in the text and areas of karst. Bathymetric contours are shown in metres and illustrate the steep declination to the west (original northwestern coastline of Sahul) and the shallow declination to the north and west where the islands were once joined to Greater Australia. of excavation in 1996. In 1996 efforts were made to find further suitable cave sites, and this resulted in the identification of Liang Nabulei Lisa (Site 22), which formed the main focus of excavation in 1997. Surveys in 1995 and 1996 also concentrated on finding midden sites likely to have mid- to late Holocene sequences. We hoped to examine the transition to agriculture and develop pottery sequences on the basis of excavation of such sites. The site with the greatest excavation potential was judged to be the Wangil midden (Site 10), located in 1995. This was excavated in 1997 . The 1997 survey extended our coverage of cave sites in the Nabulei Lisa area, but did not produce any with the archaeological potential of that site. We were thus not diverted from our plan to excavate Liang Nabulei Lisa to fill in the later parts of the Aru cultural sequence. Early to mid-Holocene deposits had not been found in Liang Lemdubu during the 1996 excavations, and Liang Nabulei Lisa was targeted in order to fill this gap.

Sites found in all years are numbered in sequence from 1 to 31 . The site descriptions given here replace those in previous publications (Spriggs et al. 1998; Veth et al. 1998).

\section{The 1995 Reconnaissance Survey of Aru}

The joint Australian-Indonesian survey team in 1995 consisted of Veth and Spriggs, and Ako Jatmiko (Puslit Arkenas). Thirteen sites were recorded on the five islands in 1995. These included two caves with cultural deposits (Sites 8 and 9); three further caves of primarily religious significance (Sites 4, 6 and 7); five midden complexes, at least three of them with associated pottery

(Sites 3, 10 to 13); a substantial fortified settlement at Ujir, possibly with an associated shipwreck (Site 5); and an early Dutch fort and nearby stone church (Sites 1 and 2). Bad weather prevented more detailed examination of the Wangil (Site 10) and Durjela (Site 11) middens, and only passing observations were made of the other surface sites. We were taken to many other cave sites on Wasir, and near Wokam and Semang villages on Wokam Island, but none showed any signs of human use and they were mostly the mouths of underground stream systems. 


\section{Sites 1 and 2 - Kota Lama Wokam}

Wokam Island ( $\left.5^{\circ} 42.465^{\prime} \mathrm{S}, 134^{\circ} 12.877^{\prime} \mathrm{E}\right)$. The first fort on the site would have been built during the mid to late 17th century. It is known locally as Kota Lama Wokam (Wokam old village). It is under the custodianship of the Education Department and is occasionally visited by tourists. The fort is adjacent to the beach and commands the entrance to the channel between Wokam and Wamar Islands (Fig. 4.2). The coral block walls are in generally good condition, and measure approximately 50 by $35 \mathrm{~m}$ with the longest axis parallel to the beach. There are remains of corner bastions, and attached to and projecting four metres out from the western, sea-facing wall is a rectangular blockhouse, $10 \mathrm{~m}$ in its greatest dimension (Fig. 4.3). There is a small entrance on the seaward side adjacent to the blockhouse and another blocked entrance on the landward side.

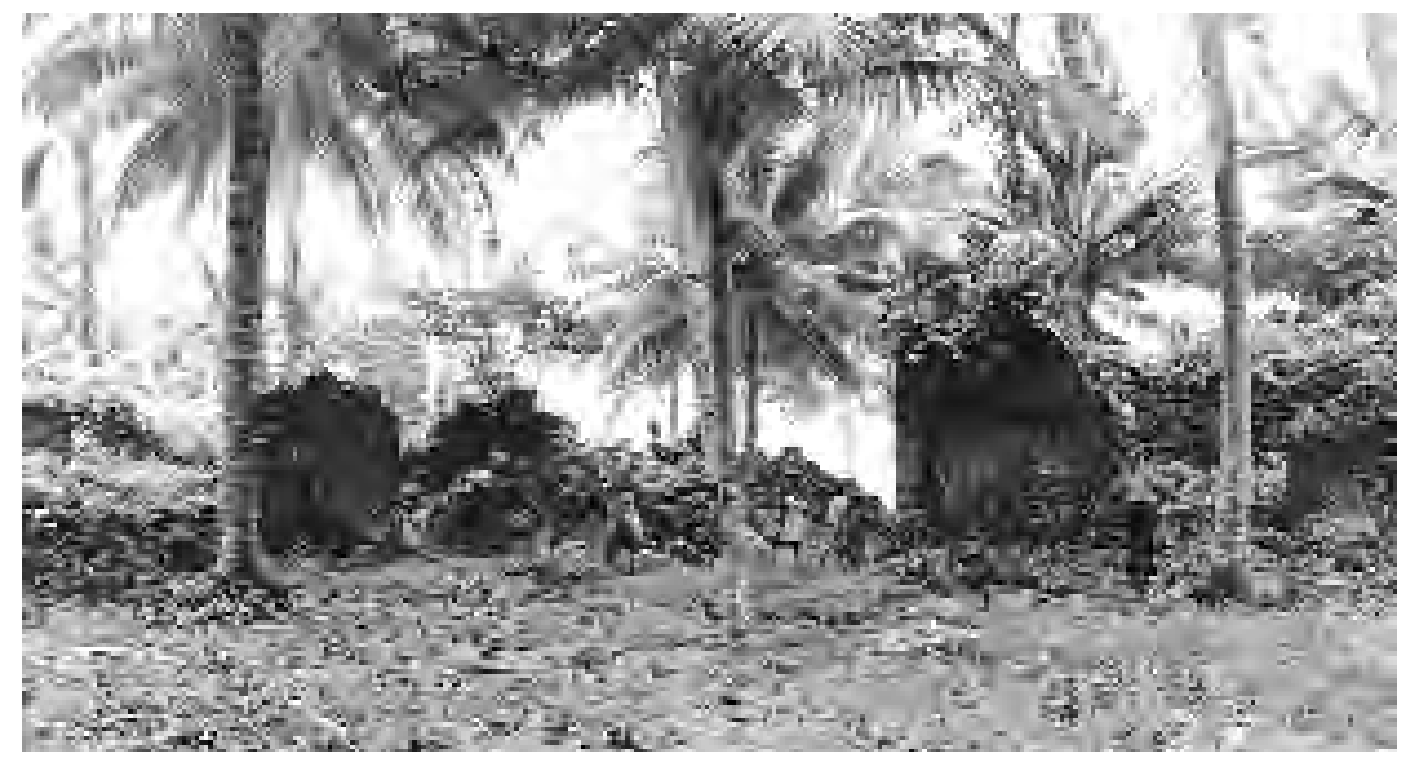

Figure 4.2 Site 1 - Kota Lama Wokam: Dutch Fort, view of rampart looking southwest

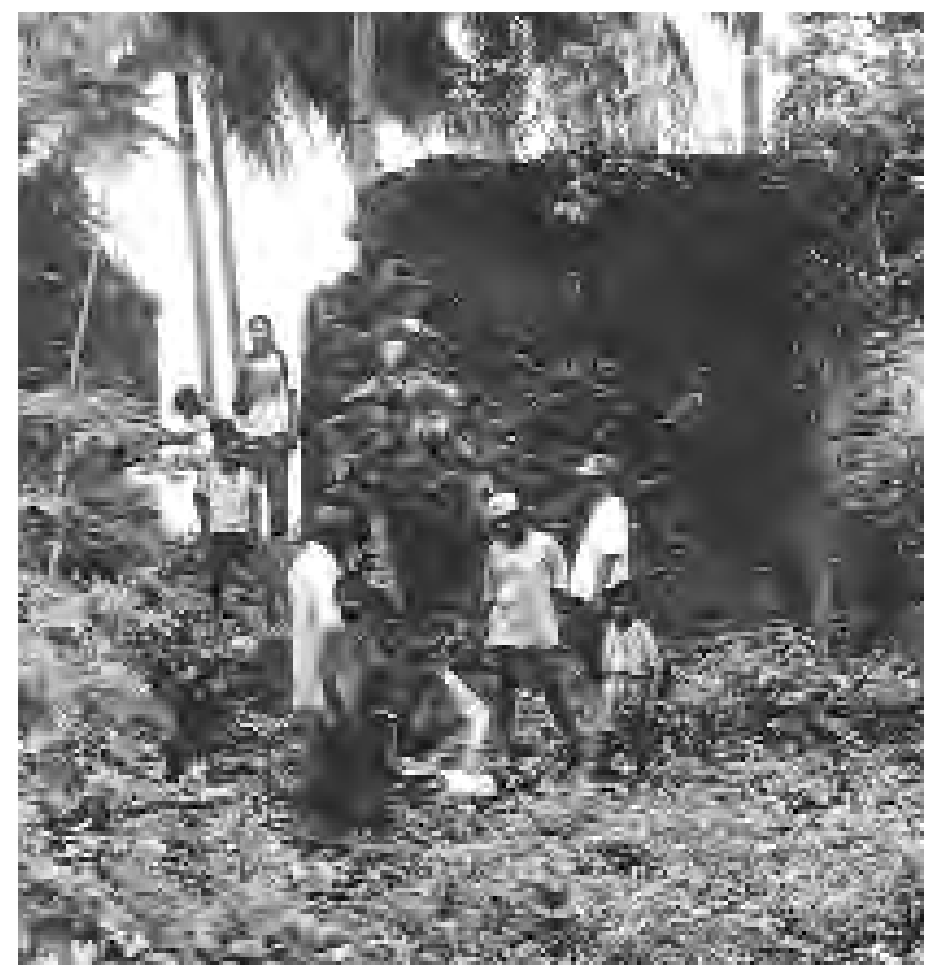

Figure 4.3 Site 1 - Kota Lama Wokam: entrance to Wokam Fort, view facing west 
Among the internal structures is a stone-walled building in the southern half of the fort, with five internal rooms and with its external walls well-preserved. Foundations of another stone building are also visible in the southern half of the fort. In the northeast corner is a stone-lined well. Coconuts have been planted within the walls. There is an entrance on the seaside immediately south of the blockhouse and a blocked larger entrance opposite it in the east, inland side with door slots preserved. Porcelain and bottle glass sherds are found inside the fort and there are dumps of porcelain and bottle glass outside the fort to the east, and between the fort and the church.

South of the fort are the remains of a stone church (Site 2), with its walls remaining to the full height in some places. The church has three windows on each side and a small door to the seaward side as well as a larger one at the inland, eastern end (Fig. 4.4). The pottery illustrated in Figure 4.5 was collected from outside the walls at the east end of the church. The present site of Wokam village is immediately south of the church site.

Valentijn (1862[1722]:III:36-8) described Wokam as the main village in the Aru Islands and noted that around $1700 \mathrm{AD}$ there were a sergeant, a corporal, and 10 or 12 soldiers stationed in the fort. Merton (1910:163) claimed that the Aru forts were abandoned in the 18th century because of

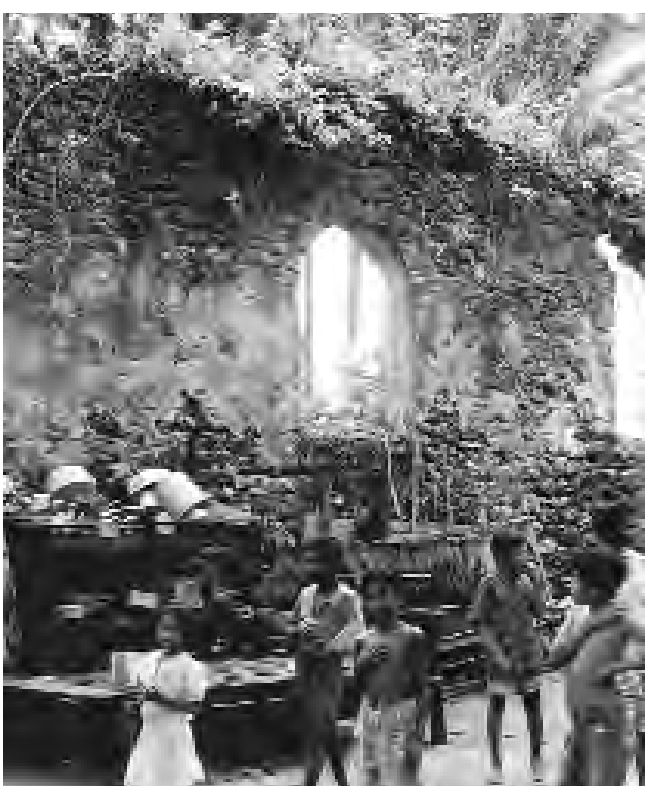

Figure 4.4 Site 2 - Kota Lama Wokam: remains of church

3)
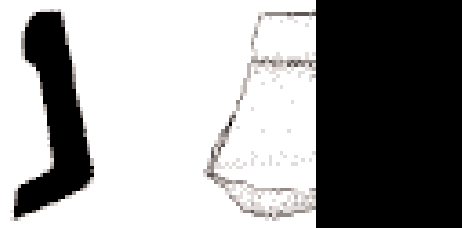

c)
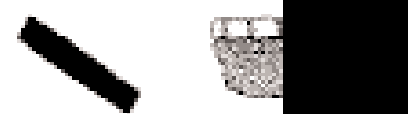
local uprisings. Wright (1958:18-9) may have been referring to this fort when he noted that a fort in Aru had to be abandoned in 1792 because of such attacks. Kolff (1840) gives a very interesting account of this fort and church from his 1826 visit. At that time the main village of Wokam was north of the fort. His description suggests that the fort was rebuilt some time after his visit:

This fort, which is now in a state of great dilapidation - patches of a wall, which was once three feet thick and twenty feet high, alone remaining - formed a square with bastions at the corners; but of the latter nothing was now visible, some posts having been erected in their place, on which several lelahs [guns] were mounted. The house of the Orang Kaya, which stands in the centre, is the only part in good repair. The natives were very desirous of having a

b)

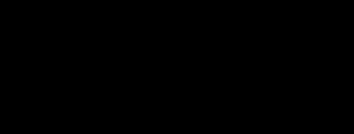

9 5 on

c)

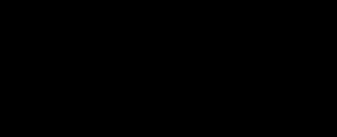

Figure 4.5 Site 2 - Kota Lama Wokam: pottery rim sherds from outside east end of church 
Dutch garrison again among them, in which they would willingly set to work and put the fort into complete order (Kolff 1840:192-3).

During his visit, the stone church was actively in use:

The church, situated on the south side of the village, is a handsome and strong stone building, and although the doors and windows are wanting, it is otherwise kept carefully in order. On each side of the entrance are benches and reading desks for the men, while a number of oldfashioned carved chairs, certainly a century and a half old, were placed in the centre for the women. Here and there gravestones might be perceived, the inscriptions of which had become illegible. Their dead are not now interred in or near the church, but are deposited in an enclosed cemetery, some distance to the north-east of the fort. The tombstones here are ornamented in different ways, and it is strong proof of the good disposition of these people, that the tombs of the officers of the late East India Company, who have died here, are kept in as good order as those of their own chiefs and forefathers ... (Kolff 1840:189-90).

Von Rosenberg (1867) adds further interesting details of the fort and church from his 1865 visit. The attack on the fort, and its abandonment by the Dutch, is given there as occurring in 1808 on the basis of a gold-knobbed cane given to the then-Orang Kaya of Ujir for his assistance to the fort commander who fled to that village during the attack. An inscription on the cane gives the date. Von Rosenberg's (1867:14) account of Wokam village is worth giving in detail:

The fourteen houses built high above the ground occupy two sides of an open square in the middle of which the [house of the] Orang kaya stands. The south side of this square is occupied by a stone church of which the brightly white-washed walls make a sharp contrast with the dark ground of the forest. Because of the absence of the Orang kaya I had to stay in the village chief's house. In the morning I visited the ruins of a large fort of the Company, which we had already passed when entering the village. Judging by the ruins in the middle of the village it must have been an enormous structure which in these far remote regions bears witness to the power and greatness of the East Indies Company. A square wall of more than 100 ells surrounded it all, a tower-like bastion, two gates and parts of the base of walls towards the sea still remain ... An inscription carved in stone, which stood above the eastern gate, cannot now be found anywhere. Nobody seemed to know the historical particulars surrounding this fort; that it was deserted in 1808 and most probably had also been destroyed.

This account suggests that some rebuilding of the fort took place after 1865, as the sea walls were fully extant when we visited in the 1990s.

\section{Site 3 - Karkur}

Wamar Island ( $\left.5^{\circ} 49.685^{\prime} \mathrm{S}, 134^{\circ} 13.190^{\prime} \mathrm{E}\right)$. South of Durjela on a walking track close to the shoreline, we visited an old village site in a cassava garden accompanied by the kepala desa of Durjela (Fig. 4.6). The site was marked by marine shell, earthenware pottery - some redslipped (Fig. 4.7) - a stoneware tempayan (large waterjar) sherd and an iron knife. The site probably dates at least in part to the last few centuries and is $200 \mathrm{~m}$ north of Liang di Karkur. Immediately behind the site are low hills $10-15 \mathrm{~m}$ high and it was not clear whether the midden had been deposited in situ or dumped downslope.

\section{Site 4 - Liang di Karkur}

Wamar Island $\left(6^{\circ} 3.40^{\prime} \mathrm{S}, 134^{\circ} 26.22^{\prime} \mathrm{E}\right)$. A small cave less than $200 \mathrm{~m}$ from Site 3, at about two metres above sea level and only $10 \mathrm{~m}$ from the beach. It was probably formed by wave action and the substrate is a soft marine sedimentary rock. The cave mouth is $2.5 \mathrm{~m}$ wide, and it extends back about $4.5 \mathrm{~m}$. Because of recent washed-in soil the ceiling is very low and the cave has to be crawled 


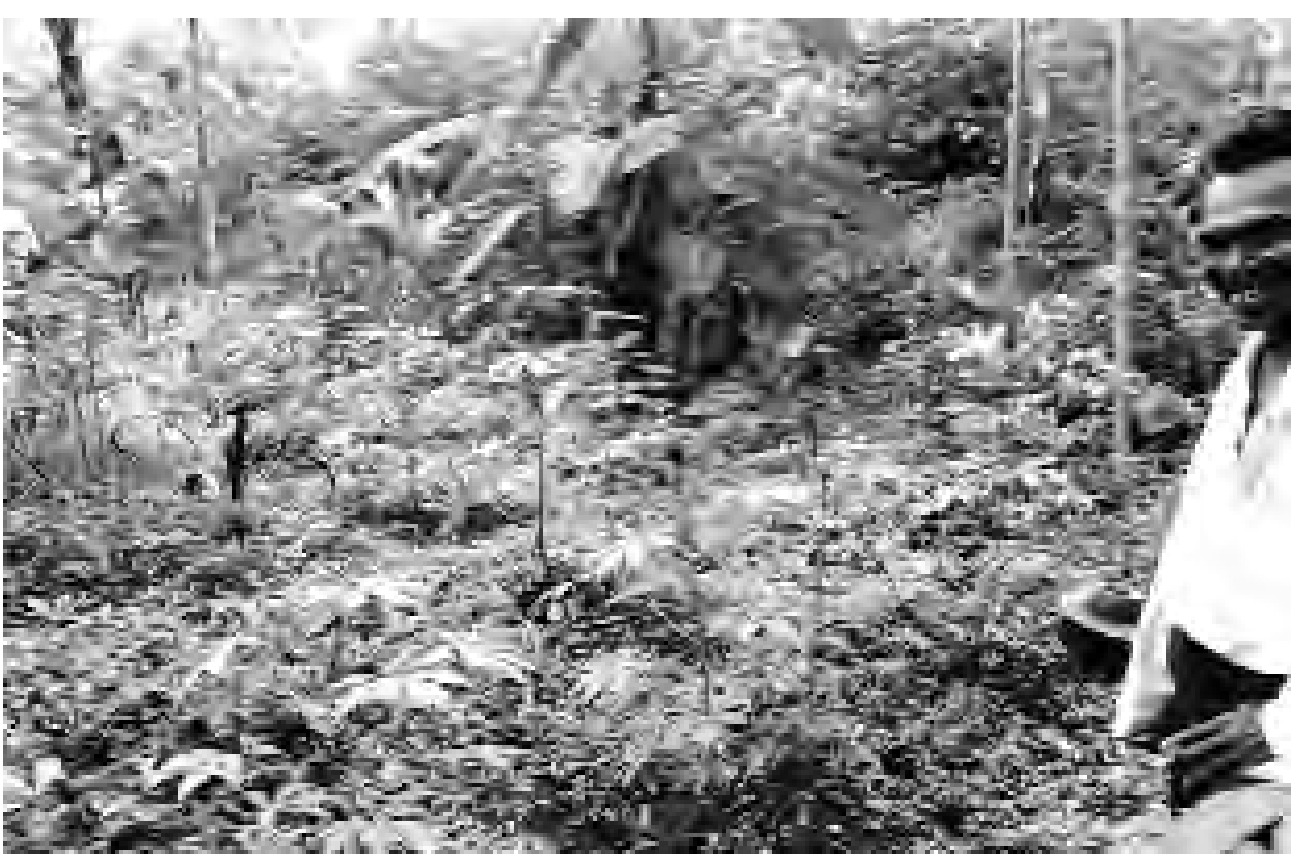

Figure 4.6 Site 3 - Karkur

a)
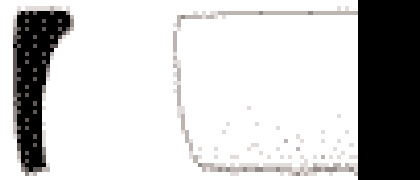

c)

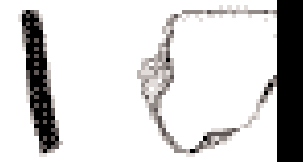

e)

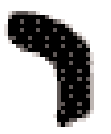<smiles>C1=CC2CCC1C2</smiles>

g)

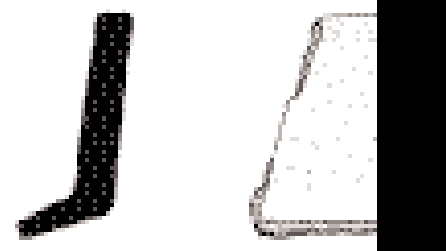

Figure 4.7 Site 3 - Karkur: pottery rim forms b)
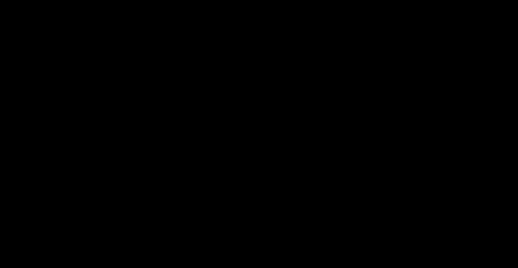

d)

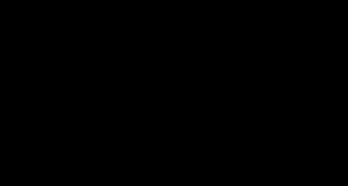

f)
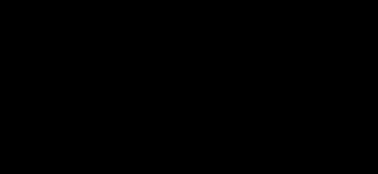

9 $5 \pi n$ 
into. The cave is used in adat (custom or tradition) ceremonies and food and drink offerings have been left at its mouth. Until recently the cave may well have been reached by high wave action and so probably has very little excavation potential.

\section{Site 5 - Ujir}

Ujir Island $\left(5^{\circ} 34.465^{\prime} \mathrm{S}, 134^{\circ} 18.080^{\prime} \mathrm{E}\right)$. This early pre-colonial trading settlement and its historical context are described and illustrated in detail in Chapter 5.

\section{Site 6 - Liang Belnarnar}

Wasir Island ( $\left.5^{\circ} 32.534^{\prime} \mathrm{S}, 134^{\circ} 15.214^{\prime} \mathrm{E}\right)$. A sacred cave owned by the people of Ujir. It is immediately behind the beach and faces southwest. It is $12 \mathrm{~m}$ wide at the mouth and is some $25 \mathrm{~m}$ deep in a soft marine sedimentary rock. The original owner of the cave was said to be buried inside and there is a stone table in the interior of the cave with offerings on it. The white sand floor and its low height above sea level - less than two metres - suggest that it has no excavation potential. The cave is very low and can only be entered by squatting. Names, some in Arabic script, have been carved in the soft marine sedimentary rock above the mouth.

\section{Site 7 - Liang Batul Bakar}

Wasir Island ( $\left.5^{\circ} 29.646^{\prime} \mathrm{S}, 134^{\circ} 15.2055^{\prime} \mathrm{E}\right)$. Another sacred cave owned by the people of Ujir. It is a solution cave in limestone about two metres above the forest floor in a $4.5 \mathrm{~m}$ high cliff and some $45 \mathrm{~m}$ behind the beach. It is wet and there is no room for habitation. The cave is three metres wide, four metres deep and about $1.3 \mathrm{~m}$ to ceiling height. Some broken porcelain was seen on the floor, presumably old offerings. There is a stone table inside and a stalagmite is said to be a person turned to stone. The cave has no excavation potential.

\section{Site 8 - Liang Lisaibam}

Kobroor Island ( $\left.6^{\circ} 3.47^{\prime} \mathrm{S}, 134^{\circ} 26.21^{\prime} \mathrm{E}\right)$. This limestone tunnel cave resembles a smaller version of Liang Lemdubu (Site 9) (Figs 4.8, 4.9). The site was located in 1995 but was revisited in 1997 in company with the landowner, Simon Sirlay, from Jirlay village, and the photographs were taken at that time.

It is located only $300 \mathrm{~m}$ from the nearest sungai and is $18.5 \mathrm{~m}$ in length, 6.7 to $7.3 \mathrm{~m}$ in width and 1.9 to $2.5 \mathrm{~m}$ in ceiling height. The cave floor has been cut through by a later channel to create a two metre wide trench that has infilled with sediments at the southern end (Fig. 4.10). The sediment infill in the deep channel appears in places to be up to one metre deep and may have some excavation potential, but there is evidence of considerable disturbance to the surface of the deposit (Fig. 4.10). The cave is aligned roughly east-west, with an eastern entrance facing $110^{\circ}$, and the west entrance facing $240^{\circ}$. It has welldeveloped shell deposits at its entrances containing the mangrove species Geloina sp. (approx. 95\%), Terebralia sp. (four per cent), Anadara sp. and other species (approximately one per cent), as well as earthenware pottery and Chinese porcelain sherds. Some deer bone was also present. The most remarkable feature of the cave is the plethora of engravings on most of its walls. Motifs include abstract geometrics, anthropomorphs and stylised feet/ hands, naturalistic representations including

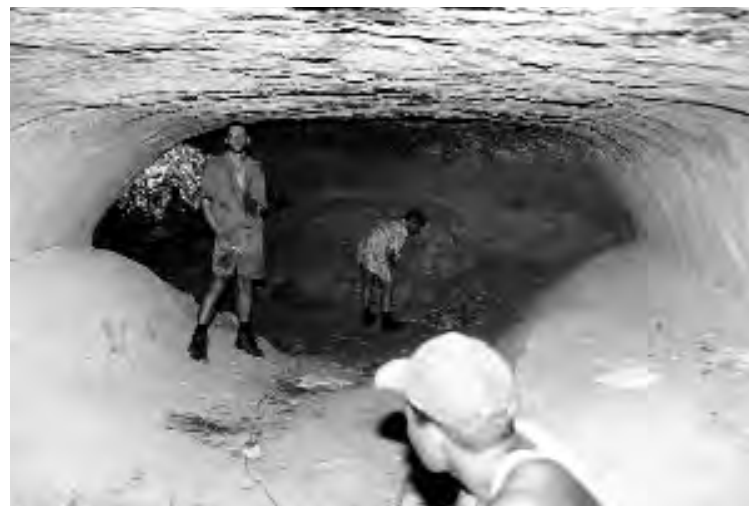

Figure 4.8 Site 8 - Liang Lisaibam: showing tunnel form of cave 


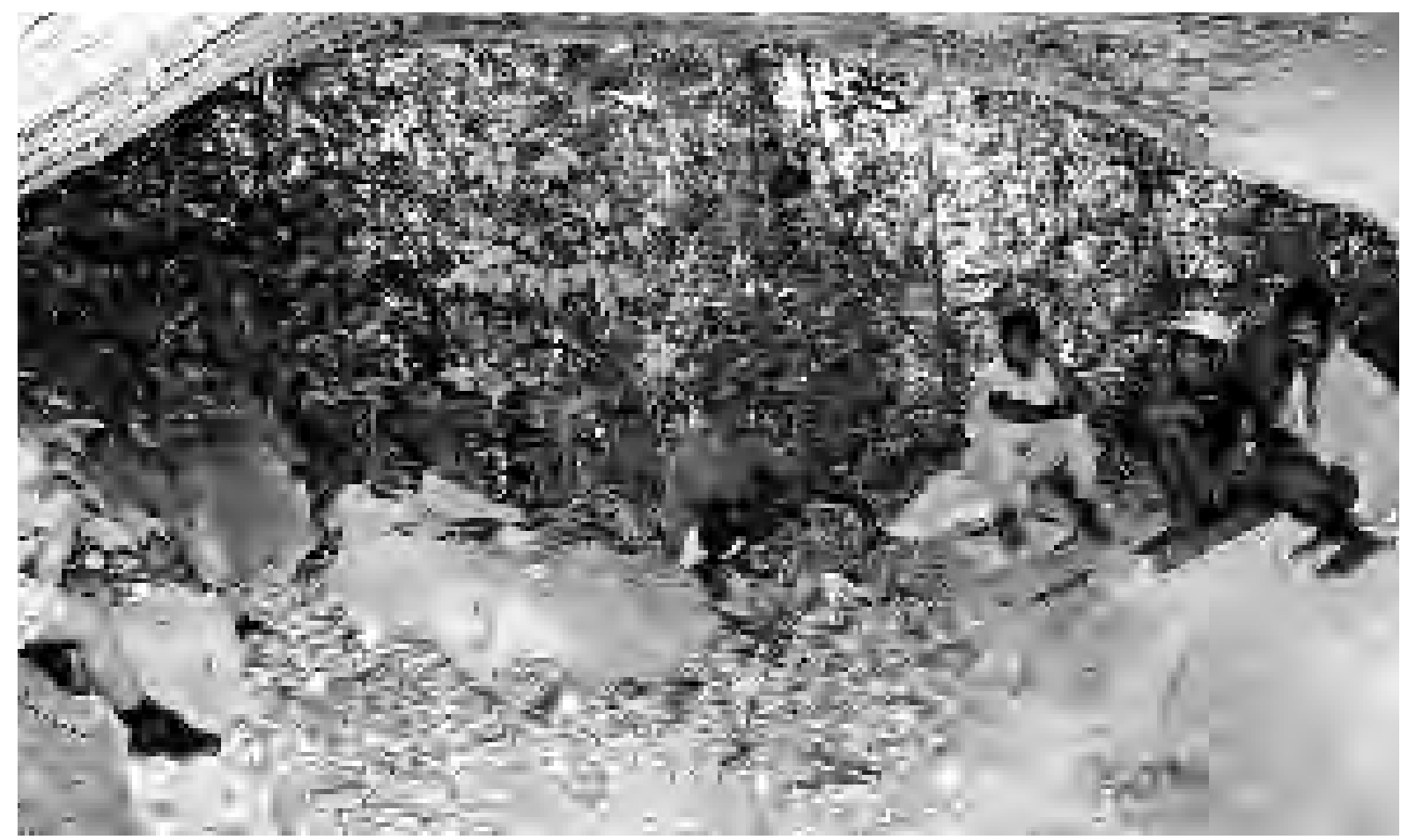

Figure 4.9 Site 8 - Liang Lisaibam: close up of midden scatter at entrance

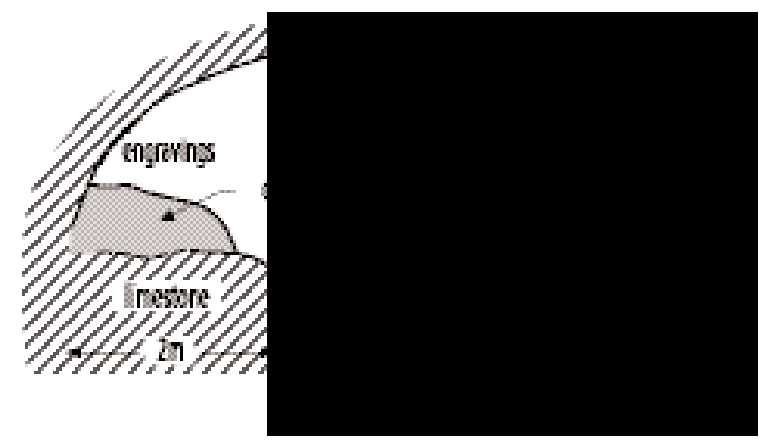

Figure 4.10 Site 8 - Liang Lisaibam: section showing channel in central floor area with deposit fill. marine craft (specifically perahu [boat] and a modern Pelni-line steamship), and crocodiles / lizards (Figs 4.11-4.15). While many of the engravings are clearly very recent - dates of 1925 and 1972 were seen - some of the art could be older, and the engraved 'branching tree' motif near the entrance has Dongson stylistic parallels and also resembles the 'tree of life' symbol common in Island Southeast Asian woven fabric designs. The 'star' motif with the radiating lines (Fig. 4.16) is ubiquitous in the painted rock art of Island Southeast Asia (O'Connor 2003). The art in Liang Lisaibam would repay detailed recording.

\section{Site 9 - Liang Lemdubu}

Kobroor Island $\left(6^{\circ} 9.13^{\prime} \mathrm{S}, 134^{\circ} 22.28^{\prime} \mathrm{E}\right)$. This site was seen as having the greatest potential to yield a long cultural sequence and was test excavated in 1996 with spectacular results. It is described and illustrated in detail in Chapter 9.

\section{Site 10 - Wangil Midden}

Wamar Island $\left(5^{\circ} 46.024^{\prime} S, 134^{\circ} 11.63^{\prime} \mathrm{E}\right)$. This was ascertained in 1995 and 1996 as having the greatest potential of the open midden sites located in those two seasons, and so was targeted for excavation in 1997. It is described and illustrated in Chapter 6. 


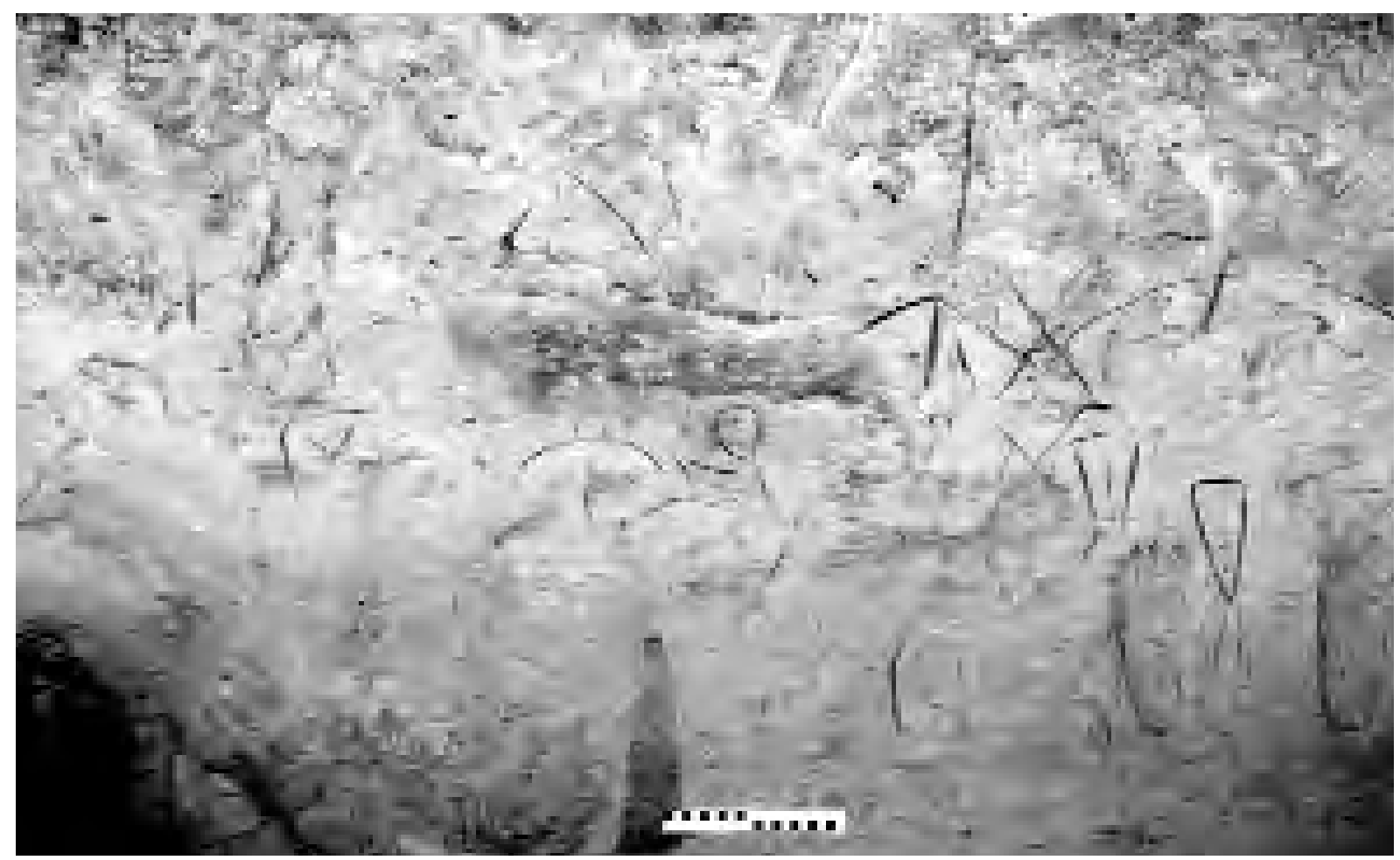

Figure 4.11 Site 8 - Liang Lisaibam: overview of engravings, geometrics, anthropomorphs, and feet

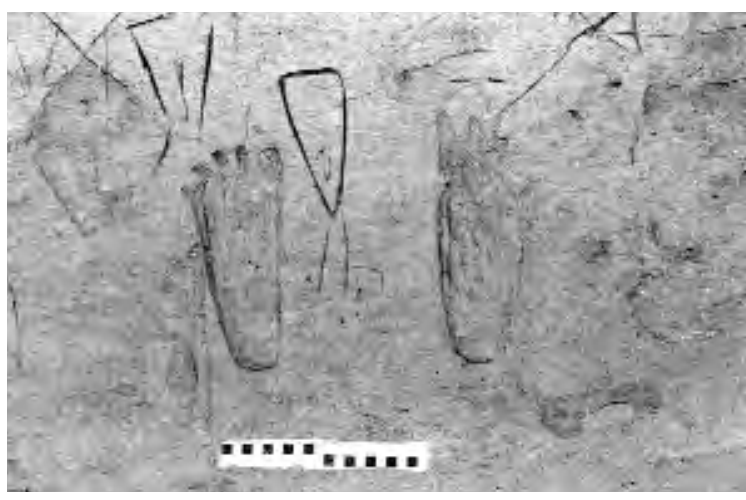

Figure 4.12 Site 8 - Liang Lisaibam: engravings, enlargement of feet and triangular incision at bottom right of Fig. 4.11

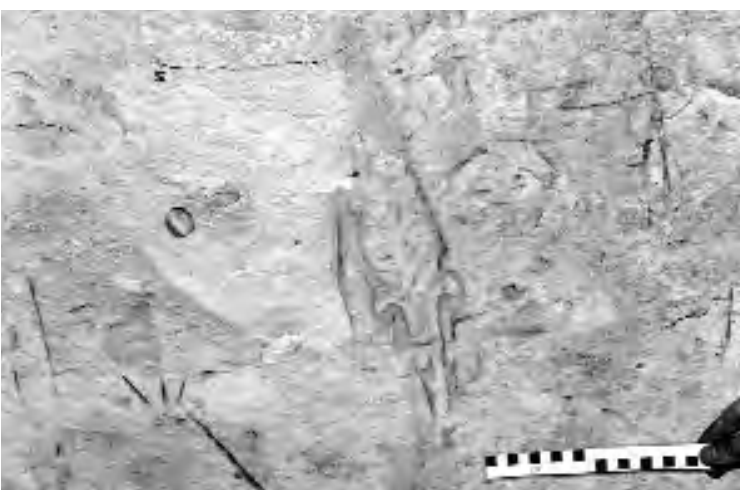

Figure 4.14 Site 8 - Liang Lisaibam: engraving of crocodile/lizard form

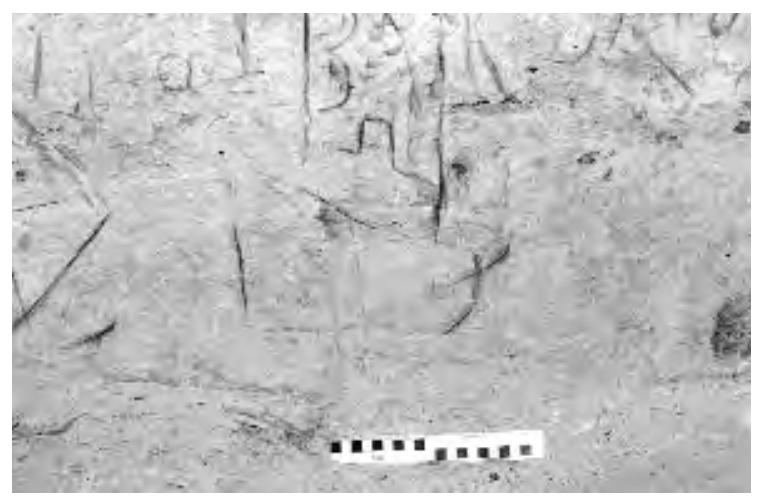

Figure 4.13 Site 8 - Liang Lisaibam: engraving of Pelni ship and letters 


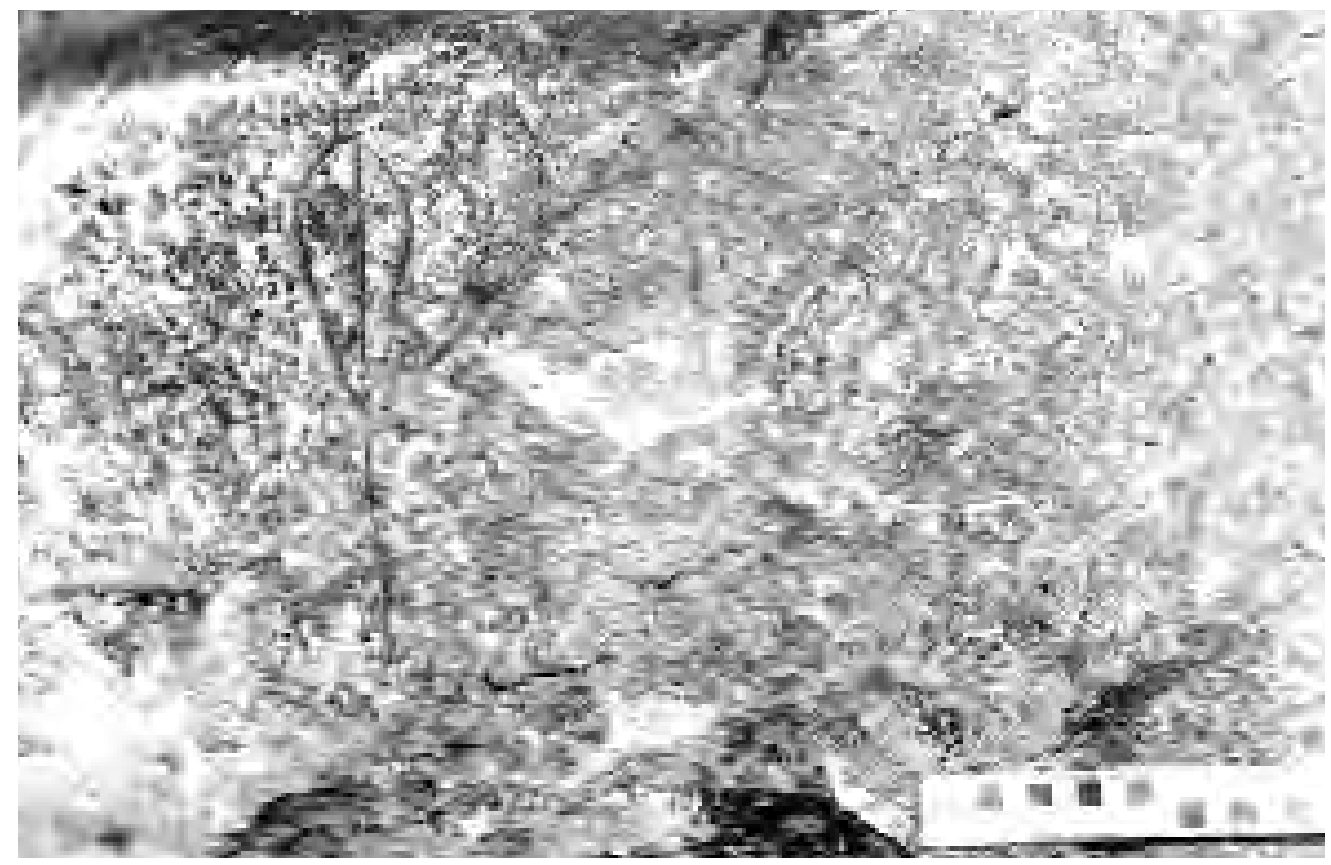

Figure 4.15 Site 8 - Liang Lisaibam: older weathered engravings including 'vulva' and 'branching tree'

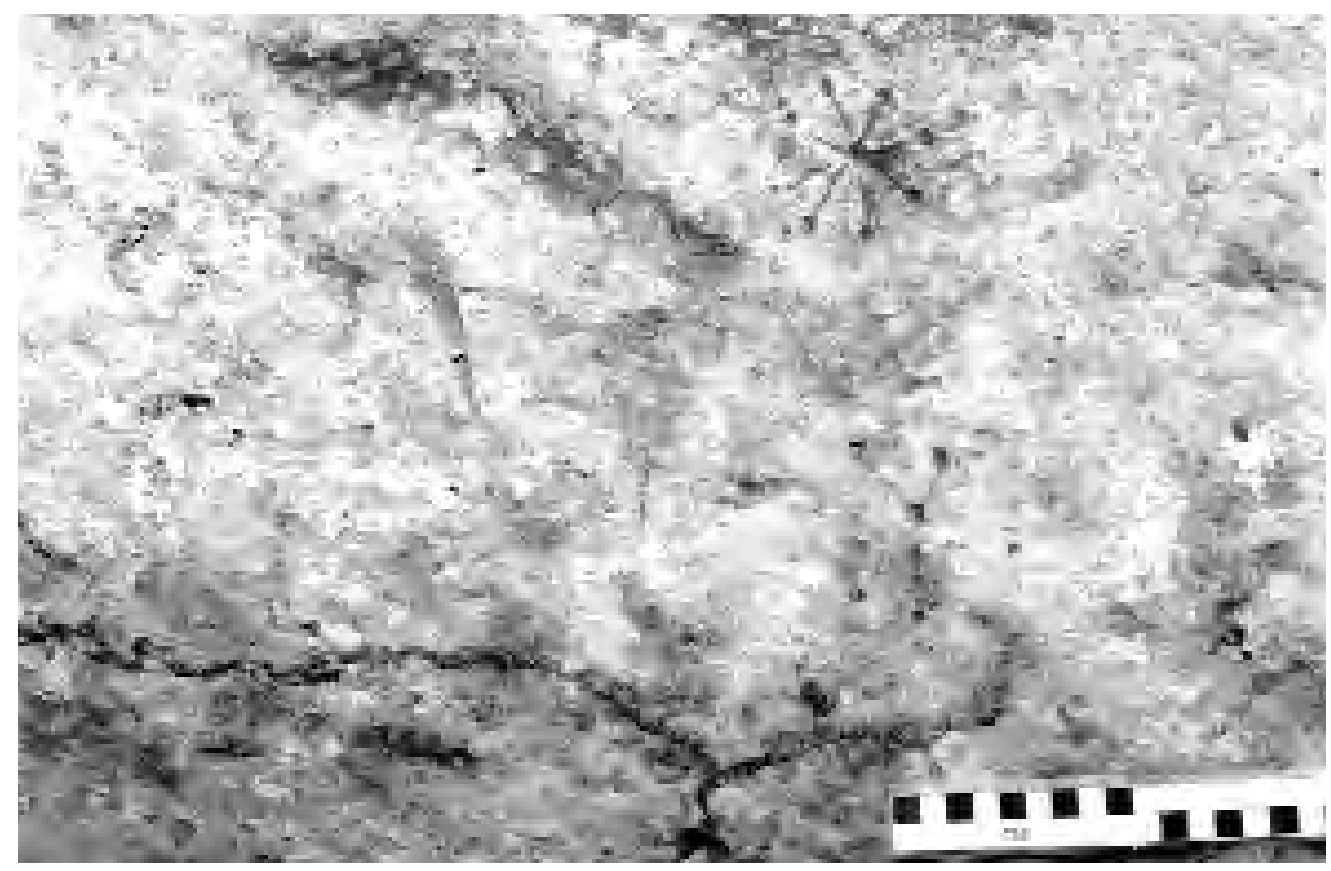

Figure 4.16 Site 8 - Liang Lisaibam: older weathered 'star' motif

\section{Site 11 - Durjela}

Wamar Island ( $\left.5^{\circ} 46.026^{\prime} \mathrm{S}, 134^{\circ} 11.63^{\prime} \mathrm{E}\right)$. Shell midden mounds were observed among the houses of Durjela village and appeared to predate the current village.

\section{Site 12 - unnamed complex}

Wamar Island (no GPS available but approximate latitude and longitude based on field map location are $\left.5^{\circ} 49.35^{\prime} \mathrm{S}, 134^{\circ} 12.71^{\prime} \mathrm{E}\right)$. Near the south coast of Wamar, along a vehicle track to the Pertamina oil complex and along a secondary vehicle track from it to Dibelakang Wamar village, 
were observed multiple shell midden exposures associated with fossil beach ridge systems (Fig. 4.17). Clearly there has been significant coastal progradation over time in this area. The area would repay further study as having the potential to provide a sequence of sites associated with beach deposits of different ages postdating mid-Holocene sea level stabilization.

\section{Site 13 - Fany Hotel Sports Field}

Wamar Island ( $\left.5^{\circ} 45^{\prime} 37.6^{\prime} \mathrm{S}, 134^{\circ} 13^{\prime} 22.1^{\prime} \mathrm{E}\right)$. This site consists of shell midden deposits exposed in the main football field adjacent to the Fany Hotel in Dobo town, near the beachside memorial to the Battle of the Aru Sea. The area has been flattened by bulldozing and so the surface may be partly disturbed. No pottery was observed in the exposed areas at this site in 1995 but some sherds were recovered from an auger hole excavated in a naturally higher area, probably an old beach ridge, near the goalpost at the Fany Hotel end of the pitch, during the 1997 field season (Fig. 4.18).

The auger revealed that the underlying stratigraphy consisted of the following: $0-5 \mathrm{~cm}$, black sandy topsoil; $5-30 \mathrm{~cm}$, grey medium sand with abundant shell midden; $30-35 \mathrm{~cm}$, very coarse calcareous sand still with some midden

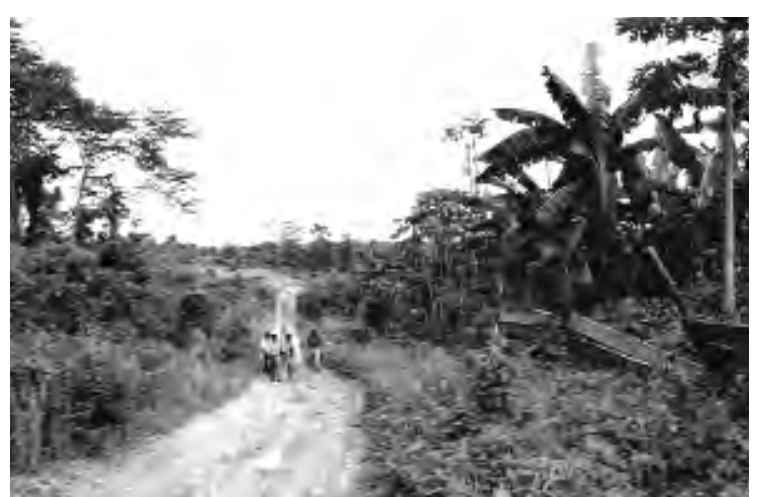

Figure 4.17 Site 12 - shell midden exposures on Wamar Island

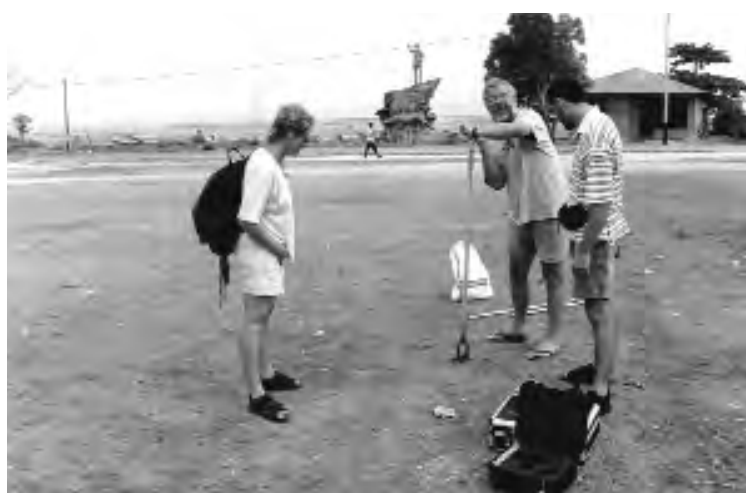

Figure 4.18 Site 13 - Fany Hotel Sports Field Midden: Geoff Hope augering ( $0^{\prime}$ Connor to left of Hope and Kelvin Gale to his right). The memorial statue to the Battle of the Aru Sea can be seen in the central rear of the frame with the exposed mud/sand flats at low tide in the distance shell (Geloina sp. only); $35-50 \mathrm{~cm}$, sterile yellowgrey coarse sand; and $50-65 \mathrm{~cm}$ plus, pale orange coarse sand of the underlying beach ridge. The midden consisted of Geloina sp., Terebralia sp. and Anadara sp. as well as small quantities of crab and fish bone. The few pottery sherds were in the top $10 \mathrm{~cm}$ of the grey medium sand unit.

The sands, which were finer-grained with depth are a typical beach ridge, but the modern shoreline is fine sandy silt. To build the beachridges that are here, the channel may have been deeper, and hence even the surface may be greater than 2000 years old. Inland of the beach ridge spit is a sago swamp ca. $1.5 \mathrm{~m}$ below the sand plain, but only in a thin deposit onto limestone. The sands mantle the northern shoreline and extend out as a spit in Dobo Town. They are a source of freshwater from wells, although surrounded by saline flats.

\section{The 1996 Reconnaissance Survey of Central and Southeastern Aru}

The 1996 survey team consisted of O'Connor, Spriggs, Veth, Mohammad, and Nayati. A further 10 sites were located during a week of survey along Sungai Manumbai and some of its branches, and on islands off the east coast of the 'mainland' of Aru, using a local 15m motor vessel as our base and transport. The smaller islands visited were Penambulai, Workai (or Barakai), and Batu Lei, although a very short period of time was spent in each location. We were told of many more sites than we had time to visit during the 1996 season, including a second Dutch fort near Dosi village on Wokam Island at Namalau Kota. We were able to visit four cave sites (Sites 14, 15, 16, and 22), and six former village sites (Sites 17-21, and 23). Sites 14, 15, and 16 were in lands controlled by Wakua village, on both sides of Sungai Manumbai, while Liang Nabulei Lisa (Site 22) 
was on Dosi village lands on Kobroor Island. As this cave site clearly had the greatest excavation potential of those visited in 1996 and 1997, it was the second cave targeted for excavation (see Chapter 7). The village sites were identified by informants from Jambu Air (Barakan Island), Afara and Beimun (Workai or Barakai Island), Batu Lei, and Dosi (Wokam Island).

\section{Site 14 - Liatai}

Kobroor Island ( $\left.5^{\circ} 56.121^{\prime} \mathrm{S}, 134^{\circ} 34.250^{\prime} \mathrm{E}\right)$. A limestone cave about three metres above the high tide mark adjacent to Sungai Manumbai. It is about two metres wide at the mouth and does not exceed this width inside, running back about $15 \mathrm{~m}$. A small hearth was found just inside the entrance but no other cultural remains were seen. The site does not have good excavation potential.

\section{Site 15 - Elan 1}

Wokam Island ( $5^{\circ} 355.612^{\prime} \mathrm{S}, 134^{\circ} 35.079^{\prime} \mathrm{E}$; called 'Elan' by the local informants). This limestone cave is on the same side of the sungai as 'Elan 2'. Elan is the Dobel language word for eagle, a bird associated with the origin myths of some of the caves we recorded. It is in a cliff face about $20 \mathrm{~m}$ above the sungai and goes through from one side of a headland to the other in a series of chambers. It is currently used for collecting birds' nests. Some shells are present at the main entrance, but what cultural deposit there is seems to be extensively disturbed by animal burrows. The site has little archaeological potential.

\section{Site 16 - Elan 2}

Wokam Island ( $5^{\circ} 55.855^{\prime} \mathrm{S}, 134^{\circ} 35.168^{\prime} \mathrm{E}$; also called 'Elan' by the local informants, and therefore designated 'Elan 2'). A limestone cave which seemed to have excavation potential. It is a large cave of several chambers that may have more than one entrance, located about $20 \mathrm{~m}$ above a mangrove swamp along a branch sungai. The entrance is quite small but this appears to be because of possibly recent stalagmitic growth. There are excavatable sediments, at least near the cave mouth. The cave had several chambers but observations were cut short when we disturbed a substantial colony of large cave bats.

\section{Site 17 - Jambu Air Lama}

Penambulai Island $\left(6^{\circ} 28.115^{\prime} \mathrm{S}, 134^{\circ} 49.796^{\prime} \mathrm{E}\right)$. This is a village site on the south coast of Penambulai Island, across the channel from the present village of Jambu Air, and ancestral to it (Fig. 4.19). We were told that it was abandoned because of an outbreak of disease, which on the basis of the porcelain and glass bottle assemblage may have occurred within the first half of the 19th century. The people then dispersed to several smaller settlements. Active erosion of a maximum five metre high sand cliff is depositing large amounts of midden material in the intertidal zone along several hundred metres of beach between a small sungai and an area of mangrove swamp. In section the midden is about $25 \mathrm{~cm}$ thick in the cliff-face (Fig. 4.20 ). Behind the eroding cliff-face are some areas of low midden mounds.

The assemblage consists of large amounts of Dutch and Chinese porcelain sherds, earthenware (similar to that produced in the Batu Lei area up to the present) (Fig. 4.21), and Dutch square liquor bottles of early 19th century type. Makers' marks on the bottles included 'NI' for 'Nederlands Indie', a cockerel, and crossed anchors with the inscription 'VAN CHARENT \& C AND D[OUB]EL ANKER'. The midden consisted of mangrove shellfish such as Geloina sp., Terebralia sp., and Telescopium sp., and occasional dugong bones. Some volcanic cobbles, possibly ballast, were present and included a large flaked cobble. The density of material suggests a rich trading centre associated with the extensive reef system between this island and the 'mainland' of Aru. Jambu Air, Waka and Lola villages form a single language group. 


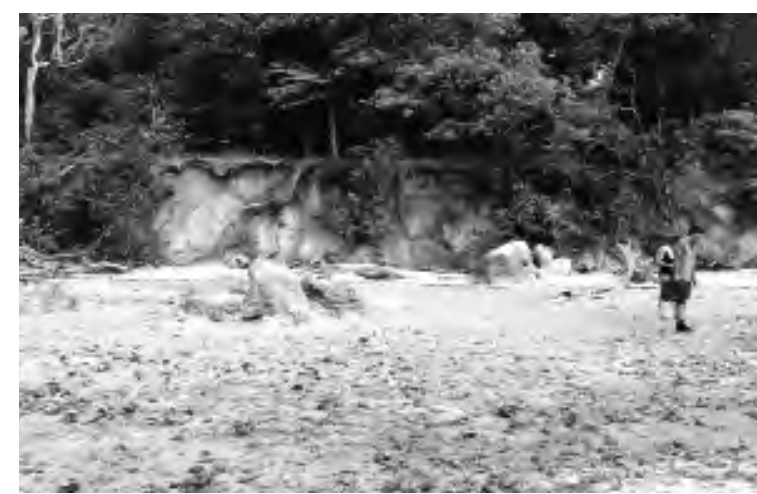

Figure 4.19 Site 17 - Jambu Air Lama: eroding sand cliffs with shell and pottery exposed in section

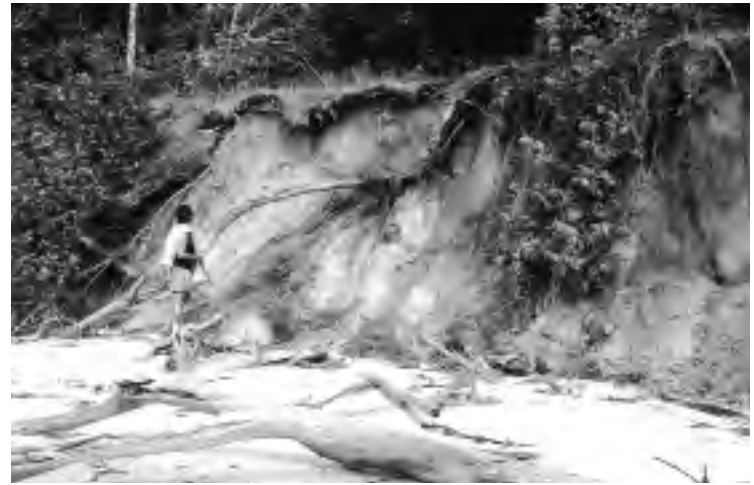

Figure 4.20 Site 17 - Jambu Air Lama: close-up of eroding section of site

b)
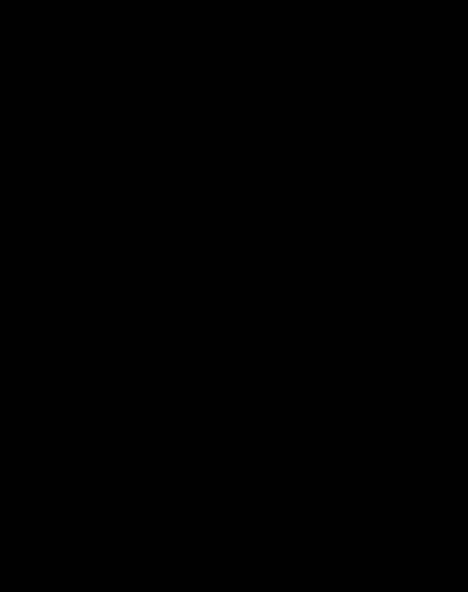

Figure 4.21 Site 17 - Jambu Air Lama: pottery rims

\section{Site 18 - Sirlasi}

Workai (or Barakai) Island (no GPS available but approximate latitude and longitude based on field map location are $6^{\circ} 46.6^{\prime} \mathrm{S}, 134^{\circ} 38.5^{\prime} \mathrm{E}$ ). This is the ancestral village site of the inhabitants of Afara and Longgar on Workai Island, and of Gomo Gomo Island (cf. Spyer 2000:20). Together they form a single language group, separate from the language of the Jambu Air people. We were told that it was an uncertain supply of fresh water which forced the abandonment of this settlement. Again, an early 19th century date seems likely on the basis of the ceramic and glass bottle assemblages which are very similar to that from Jambu Air Lama. One bottle had a round lozenge with maker's mark 'JOHN ALBERTY VIEUX COGNAC 1815 BORDEAUX', and others included potentially datable inscriptions and motifs. Among such on square bottles were 'NI', the crossed anchor motif as at Site 17, 'JH HENKES' with a long-footed wading bird motif, 'P HADEWIKERS \& $\mathrm{Co}^{\prime}$ ' on the base and 'DE VALK' at the top with the motif of a bird on a branch, and 'ROTTERDAM INTERNATIONALE CA' (rest broken off) with a coat of arms motif flanked by lions. One of the round bottle bases has part of a label 'NHAVN', presumably 'KØBENHAVN'.

The site is on a peninsula, above low, limestone cliffs, and has views to sea on three sides. It looks out over an extremely large area of reef flat and so controls an extremely rich marine 
environment. The core of the site is an area of dense midden at its southern end, with midden mounds up to three metres in height. There seemed to be a wider range of earthenware rim forms at this site than at Site 17, although the fabric was similar (Fig. 4.22). The shell species present were also similar. Notable finds included porcelain sherds and at least one piece of earthenware which had been flaked into round discs, perhaps as counters for a game, and also a stone pestle decorated with incised designs on its sides, and a stone flake. A similar, though smaller, type of settlement to Jambu Air Lama seems to be indicated by the remains.

Workai Island was already famous by 1824 as a source of trepang and black pearls and Kolff (1840) gives a detailed account of the preparation and trade in these commodities as witnessed by A.J. Bik in 1824 (see Spyer 2000:295). Sirlasi is probably the site he refers to as 'Old Affara':

a)
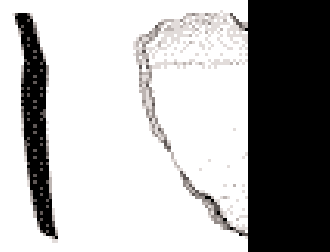

b)

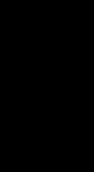

0 5en

Figure 4.22 Site 18 - Sirlasi: earthenware sherds

Among the chief villages on Vorkay, are Old and New Affara, Longa, Uri and Goor, before the last of which lies a great pearl bank. The natives informed me it was exhausted, and that they had not fished it for two years ... (Kolff 1840:177)

\section{Site 19 - Tanjung Goljurong}

Workai (or Barakai) Island ( $6^{\circ} 44.614^{\prime} \mathrm{S}, 134^{\circ} 42.553^{\prime} \mathrm{E}$ ). This village site is situated on an extensive headland surrounded by vast shoal reef flats on the east coast of Workai, north from Beimun. According to Spyer (2000:20) the Beimun people claim it as the site of their ancestral village of Wonusomor (Seltimor in Malay), and their stories stress its impressive size as a 'city'.

This site appears to have been abandoned earlier than Sites 18 and 19, as it had small amounts of porcelain but no bottle glass. The earthenware assemblage is considerable in size and similar to the previous sites including a number of decorated perforated rims. The dense shell midden deposit at this site appears to be up to $1.5 \mathrm{~m}$ in depth.

\section{Site 20 - Wangang}

Batu Lei Island (no GPS available but approximate latitude and longitude based on field map location are $\left.5^{\circ} 49.2^{\prime} \mathrm{S}, 134^{\circ} 47.7^{\prime} \mathrm{E}\right)$. This village site is a few hundred metres south of the present village of Batu Lei, on the island of that name. The villagers were reticent to give us information about the history of the site, or details of any other sites in this area in the absence of the kepala desa. Wangang is situated on low, limestone cliffs adjacent to a small embayment. Although not examined in situ, large quantities of ceramics and bottles, both square and round, were clearly visible in the intertidal silt below the cliffs. It also contained quantities of earthenware similar to contemporary Batu Lei pottery (Fig. 4.23). The site is currently under coconuts and showed signs of having been recently gardened (Fig. 4.24).

A fairly sparse scatter of material over a limited area of the headland may not do justice to the size or importance of the site when the material dumped over the cliff is taken into account. The site was abandoned sometime after 1926 as a man of 70 years whom we met had been born there. It contained some early 20th century Dutch ceramics as well as earlier Dutch and Chinese porcelain. Several pieces of Dutch porcelain had the name 'Petrus Regout and Co, Maastricht, Made in Holland', and in one case had what appeared to be writing in Thai script below. One piece from this company also included the date 1836. Contemporary pottery making in Batu Lei village is discussed in Chapter 6. 
a)

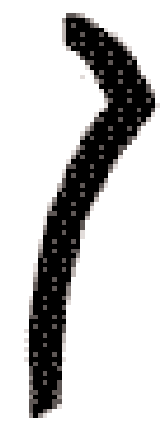

c)
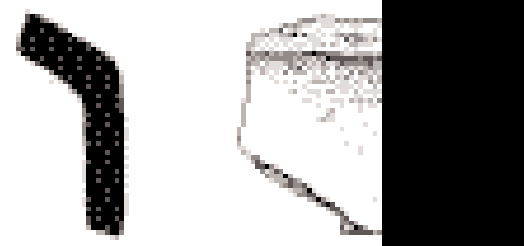

Figure 4.23 Site 20 - Wangang: pottery rims

\section{Site 21 - Nyanyapati}

Kobroor Island (no GPS available but approximate latitude and longitude based on field map location are $6^{\circ} 0.00^{\prime} \mathrm{S}, 134^{\circ} 32.7^{\prime} \mathrm{E}$ ). This is a former settlement site located close to and on the other side of Sungai Nyanyafafi from Liang Nabulei Lisa (Site 22). It is an ancestral site for one of the Dosi village families. Houses there would have had to be of stilt construction, given the rough limestone surface and the tidal range in the area. Such houses can be seen today close to the site. Only occasional sherds of porcelain were seen in the area, including blue and white Chinese trade ware (Fig. 4.25), and 20th century Dutch and Indonesian types. It appeared to represent only a hamlet-sized interior settlement.

\section{Site 22 - Liang Nabulei Lisa}

Kobroor Island ( $\left.6^{\circ} 00.112^{\prime} \mathrm{S}, 134^{\circ} 33.627^{\prime} \mathrm{E}\right)$. This massive tunnel cave was excavated in 1997. See Chapter 7 for a description of the cave, its excavation, and the cultural assemblage. We were told of other caves in this area, away from the sungai, with which it could be usefully compared, and some of these were visited in 1997 (see below for sites 24, 25 and 26). b)
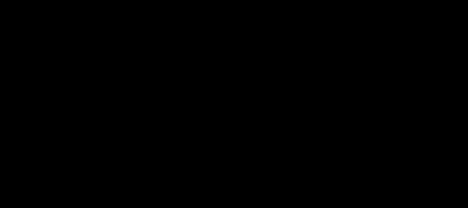

4 5 प1

d)
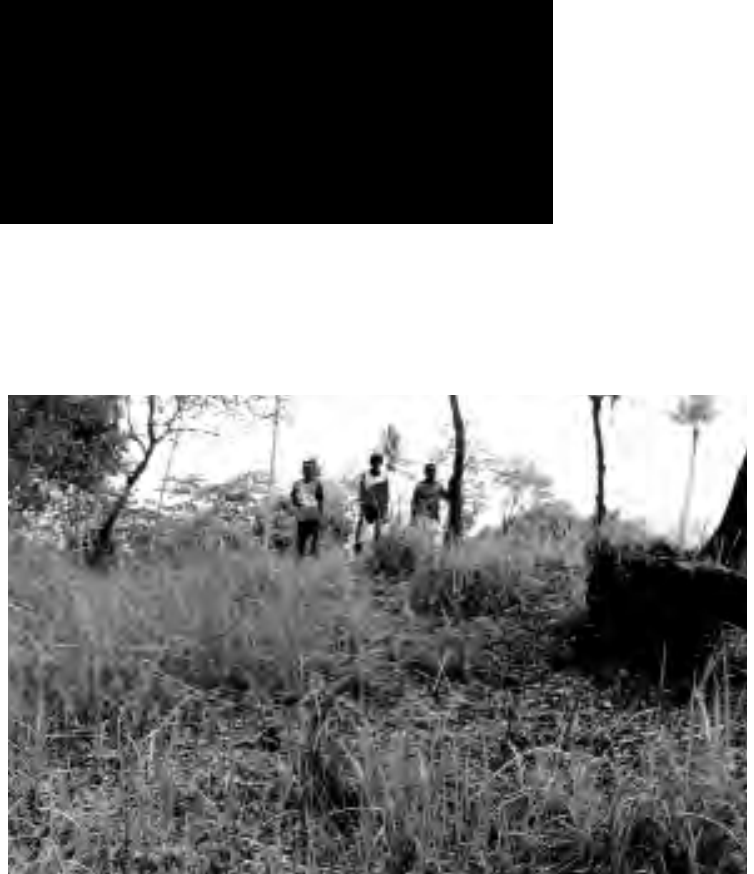

Figure 4.24 Site 20 - Wangang: pottery and shell exposed in area which has been previously cleared and gardened

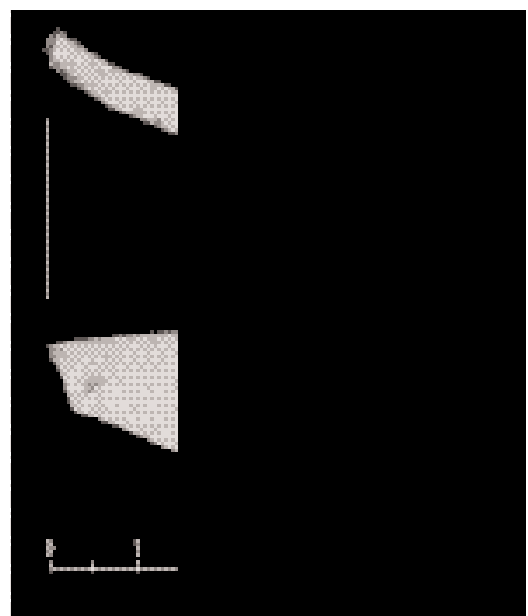

Figure 4.25 Site 21 - Nyanyapati: first kota lama, chinese blue and white porcelain 


\section{Site 23 - Dosi Namalau}

Wokam Island ( $\left.5^{\circ} 56.367^{\prime} \mathrm{S}, 134^{\circ} 36.502^{\prime} \mathrm{E}\right)$. This is a large village site apparently abandoned about 1945 when several families came together to form the present village of Dosi. It is situated on the north bank of Sungai Manumbai (Fig. 4.26). Its location is significant as it is one of the few places along the sungai east of Papakulah Besar where limestone fingers down to the shore and larger vessels can anchor directly adjacent to the land. Steps have been cut into the limestone at this point to give access to the site, which is on the side of a limestone hill perhaps some $50 \mathrm{~m}$ above the sungai. On the sides of the hill, which appears to have been artificially terraced, is a dense scatter of mangrove shellfish, porcelain, earthenware and occasional pieces of metal cooking pots and other artefacts (Fig. 4.27). There does not appear to be any deep cultural deposit and the site may be comparatively recent in age. A small-capacity spring of drinking water is located on the side of the hill.

\section{The 1997 Reconnaissance Survey}

Survey in 1997 targeted further interior cave sites in the Sungai Manumbai area, prior to choosing to excavate Liang Nabulei Lisa (Site 22) as the most prospective of those visited. In addition, an examination of the vicinity of the Wangil Midden (Site 10) on Wamar Island prior to excavation there, located a 17th century Dutch fort. The survey and excavation team in 1997, in addition to O'Connor and Veth, consisted of Geoff Hope (Research School of Pacific and Asian Studies, ANU), Aliza Diniasti Saleh and Djoko Witjaksono (Puslit Arkenas), and Kelvin Gale (then of James Cook University, Townsville). A further seven cave and/or rockshelter sites were recorded during the

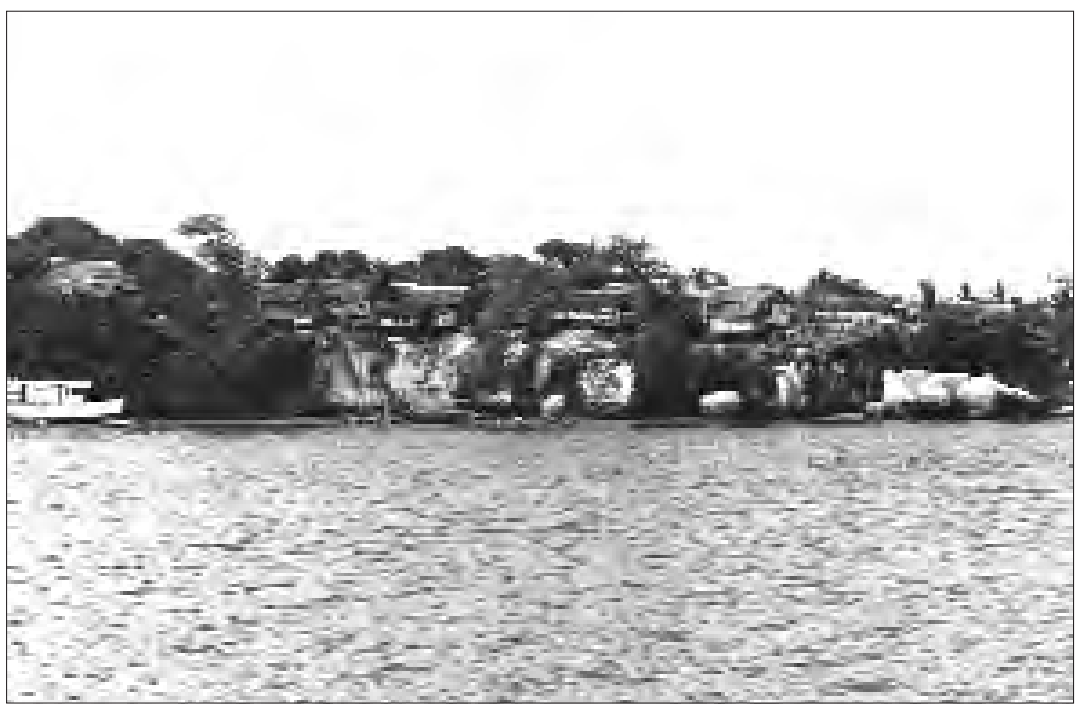

Figure 4.26 Site 23 - Dosi Namalau: the steps of the old kota lama (centre left just above the sungai) a)
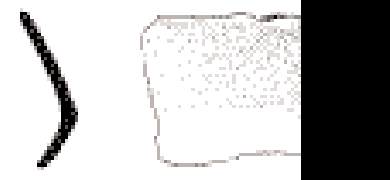

( b)

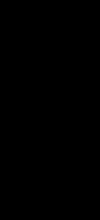

50

Figure 4.27 Site 23 - Dosi Namalau: rim and carination 1997 season. In addition, the midden near the Hotel Fany on Wamar (Site 13) was sampled by auguring and Liang Lisaibam (Site 8) was revisited and the rock art photographed. For convenience the additional information obtained from these two sites is integrated within the original site descriptions of the 1995 season.

\section{Site 24 - Lisa Karar}

Kobroor Island (no GPS available but approximate latitude and longitude based on field map location are $6^{\circ} 01.6^{\prime} \mathrm{S}, 134^{\circ} 32.4^{\prime} \mathrm{E}$ ). The cave is in a broad ridge about $1.5 \mathrm{~km}$ south of Liang Nabulei Lisa, above the extreme limit of mangrove growth. This is another former underground river channel forming a tunnel cave, similar to Liang Lemdubu (Site 9) and 
Liang Nabulei Lisa (Site 22). It is oriented north-south and is approximately 50m long with its widest point near the southern entrance of some $14 \mathrm{~m}$. Its width decreases to nine metres in the middle, $7-8 \mathrm{~m}$ in the northern quarter, and approximately $6-7 \mathrm{~m}$ wide near the northern entrance. The height of the cave is about eight metres and remains relatively consistent throughout. At both the northern and southern ends talus slopes probably formed by roof collapse drop about 20 degrees and approximately eight metres into the cave. The useable floor space or potential 'living area' within the cave is only about 18 by eight metres. There could be a substantial depth of sediment here, trapped by the roof collapses at the entrances. The cave roof is only a few metres thick.

Surface midden consists of abundant and sizeable Geloina sp. and Terebralia sp. shell, as well as pig and deer bone. The bones show evidence of having been chewed by murids. Potsherds on the surface are similar to those seen at Liang Nabulei Lisa. Modern use appears to be as a temporary camp when hunting or sago processing in the vicinity, and when collecting birds' nests in the cave. The floor consists of dusty, dry cave earth. Recent hearths occur at the northern entrance. Wooden platforms associated with this latter activity are found on the cave floor. Further disturbance has been caused by wild pig wallowing, with individual wallows being about 1.5 by one metre and some $30 \mathrm{~cm}$ deep.

\section{Site 25 - Lisa Sadum}

Kobroor Island (no GPS available but approximate latitude and longitude based on field map location are $6^{\circ} 01.6^{\prime} \mathrm{S}, 134^{\circ} 32.4^{\prime} \mathrm{E}$ ). A smaller cave with a single entrance facing north, $10 \mathrm{~m}$ west of Site 24 . It is approximately $10 \mathrm{~m}$ long and eight eight metres wide, with a domed ceiling to a height of $3.5 \mathrm{~m}$. The potential living floor is gravelly and sloping. It measures about $6 \times 4 \mathrm{~m}$. There are perched stalactites joined by flowstone to the wall about one metre above the present floor. They suggest that the floor level has dropped about one metre, possibly because of solution of the underlying basal sediments (cf. Glover 1979 for a similar process affecting limestone caves in Sulawesi), or alternatively as a result of erosion of the cave floor. The surface sediments on the cave floor are gullied and cracked indicating that water enters in the wet season. The sediments are unlikely to have much depth as there are indications that they are continually washing out.

Pottery, shell midden (Geloina sp. and Terebralia sp.), landsnail and bone are present on the floor and in a large (dry) splash pool which has created a lag deposit of calcium carbonate encrusted midden materials.

\section{Site 26 - Arkwai Sala}

Kobroor Island (no GPS available but approximate latitude and longitude based on field map location are $6^{\circ} 01.8^{\prime} \mathrm{S}, 134^{\circ} 33.3^{\prime} \mathrm{E}$ ). This cave occurs adjacent to a dry channel and is a cut-off cave on the edge of a ridge, hence younger than the ridge crest caves. It is thus more related to modern hydrology. The cave is approximately two kilometres south of Liang Nabulei Lisa. This is another former underground river channel forming a tunnel cave, but in this case has a sinuous rather than straight course (Fig. 4.28). It is about $45 \mathrm{~m}$ long, five metres wide at its south entrance and perhaps a metre wider at its northern entrance. About half of the width of the south entrance is blocked by stalactites and flowstone - the flowstone emanating from just below the ceiling and covering all but a small area of the floor. The cave ceiling is smooth and

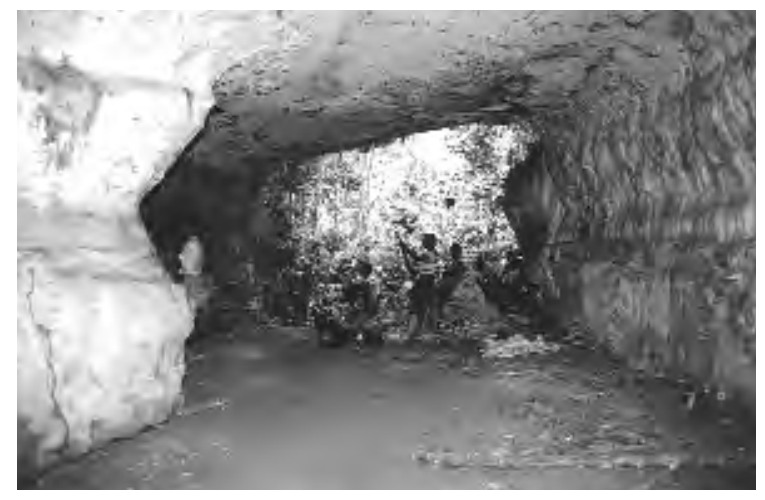

Figure 4.28 Site 26 - Arkwai Sala: the cave 


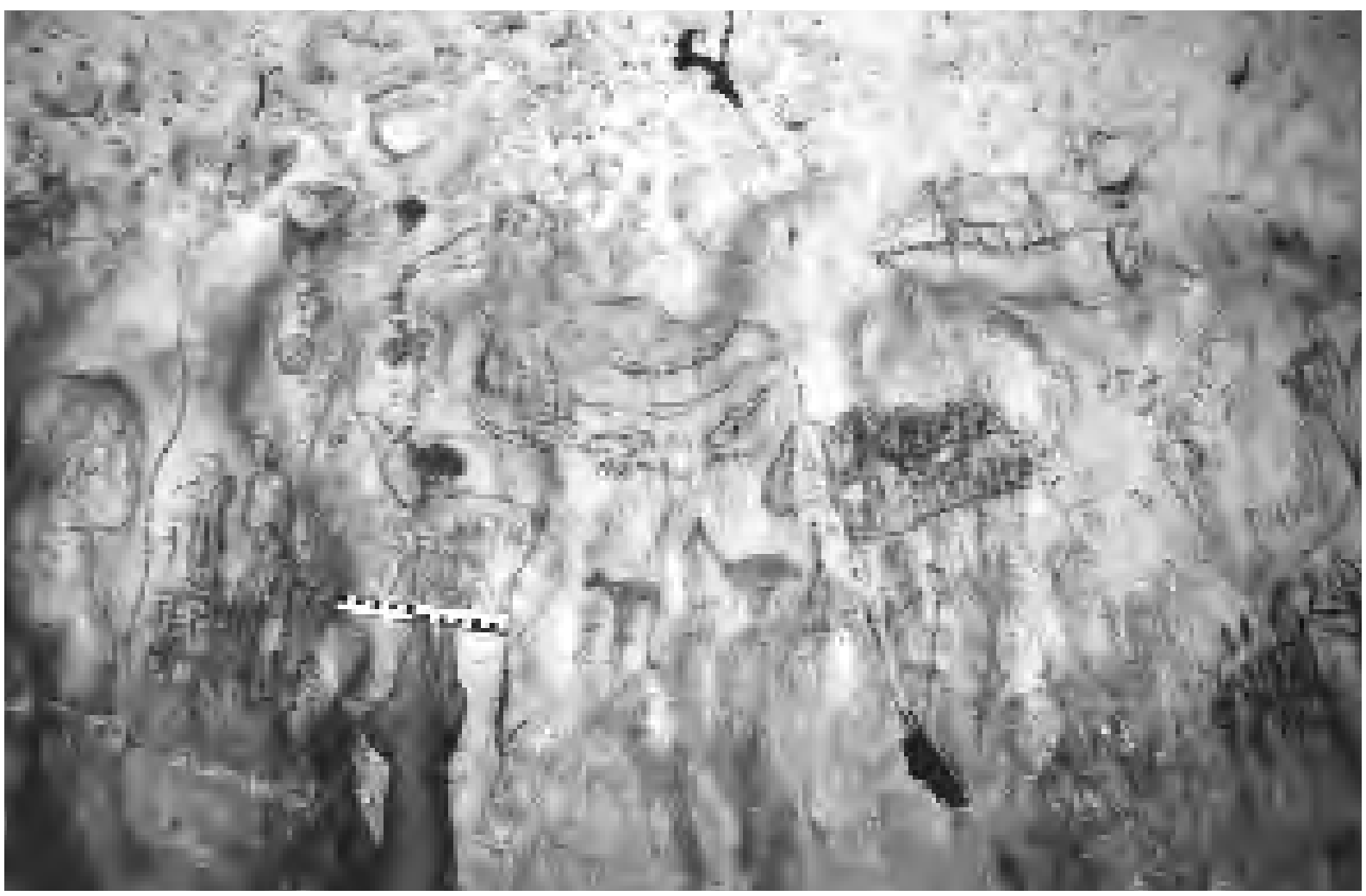

Figure 4.29 Site 26 - Arkwai Sala: the art

approximately 3.5 to four metres in height. The cave floor consists of bedrock and there is thus no excavation potential. A modern hearth is found near the northern entrance and it is at this end of the cave that recent rock drawings are found, some dated 1925, 1965 and 1988. The drawings are mostly executed in charcoal and depict soldiers, boats, men with bows and arrows, birds, deer, and dogs (Fig. 4.29). As with the engravings at Liang Lisaibam (Site 8), it would appear that the charcoal drawings at Arkwai Sala were executed over a considerable time period and include both contemporary and more traditional subjects.

\section{Site 27 - Tengum Lisa}

Kobroor Island $\left(6^{\circ} 04.08^{\prime} \mathrm{S}, 134^{\circ} 28.77^{\prime} \mathrm{E}\right)$. This is another tunnel cave four kilometres from a sungai and at $60 \mathrm{~m}$ altitude (Fig. 4.30). It is formed in the side of a north-south sloping ridge and has two branch entrances at the south end, joining to form a single chamber inside with a single northern entrance. The southern entrances are both about one metre wide while the northern entrance is

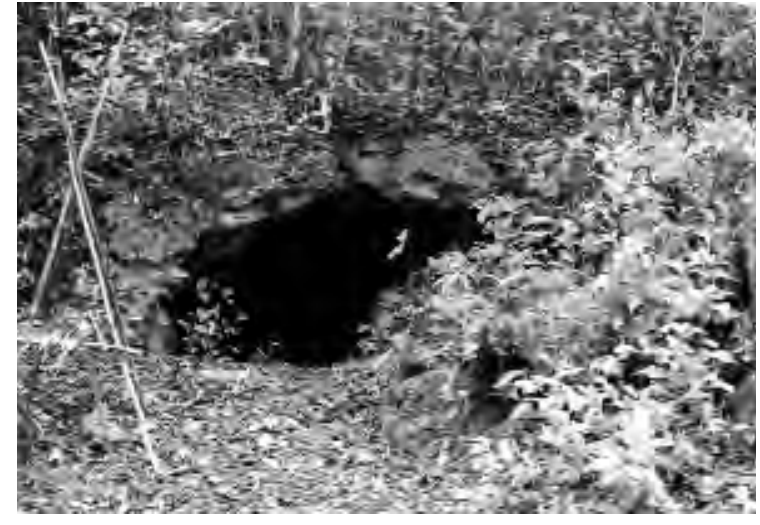

Figure 4.30 Site 27 - Tengum Lisa about four metres wide, the width of the main chamber. The cave is $15 \mathrm{~m}$ long and ceiling height is about $1.7 \mathrm{~m}$. It has a dry cave earth floor, littered with large quantities of recent habitation debris from its use as a hunting camp. Associated with several recent hearths are meat-smoking racks, and the northern entrance ceiling is fire-blackened. Glass bottles and cutdown plastic water bottles litter the floor, along with Geloina sp. shell, pig tusks, pig and deer bones. No surface pottery was seen. The deposit appears to have good excavation potential. 
Although the floor area is much smaller than at caves such as Lemdubu and Nabulei Lisa, Tengum Lisa would make an interesting comparison as a functionally-specific hunting bivouac.

Tengum Lisa is located about $400 \mathrm{~m}$ from a permanent waterhole in a doline, called tengum, and the proximity of freshwater obviously attracts game to this locale. A recently constructed hunting hide adjacent to the doline, which we were told was constructed to hunt birds of paradise, attests to this (Fig. 4.31).

\section{Site 28 - Silu Bata Bata}

Kobroor Island (6 $\left.6^{\circ} 01.21^{\prime} \mathrm{S}, 134^{\circ} 23.55^{\prime} \mathrm{E}\right)$. Silu Bata Bata is a burial shelter on the edge of the karst formation, owned by the people of Silu Bata Bata village which is directly across Sungai Manumbai on Wokam Island (Fig. 4.32). It is formed by a shallow overhang, perhaps originally cut by the sungai itself. At high tide the cave is about $1.5 \mathrm{~m}$ above the water level. Inside are about 40 or 50 skulls as well as neat piles of long bones. Extensive grave goods include Trochus sp. shell armbands, Chinese trade porcelains, Dutch VOC-era ceramics, brass

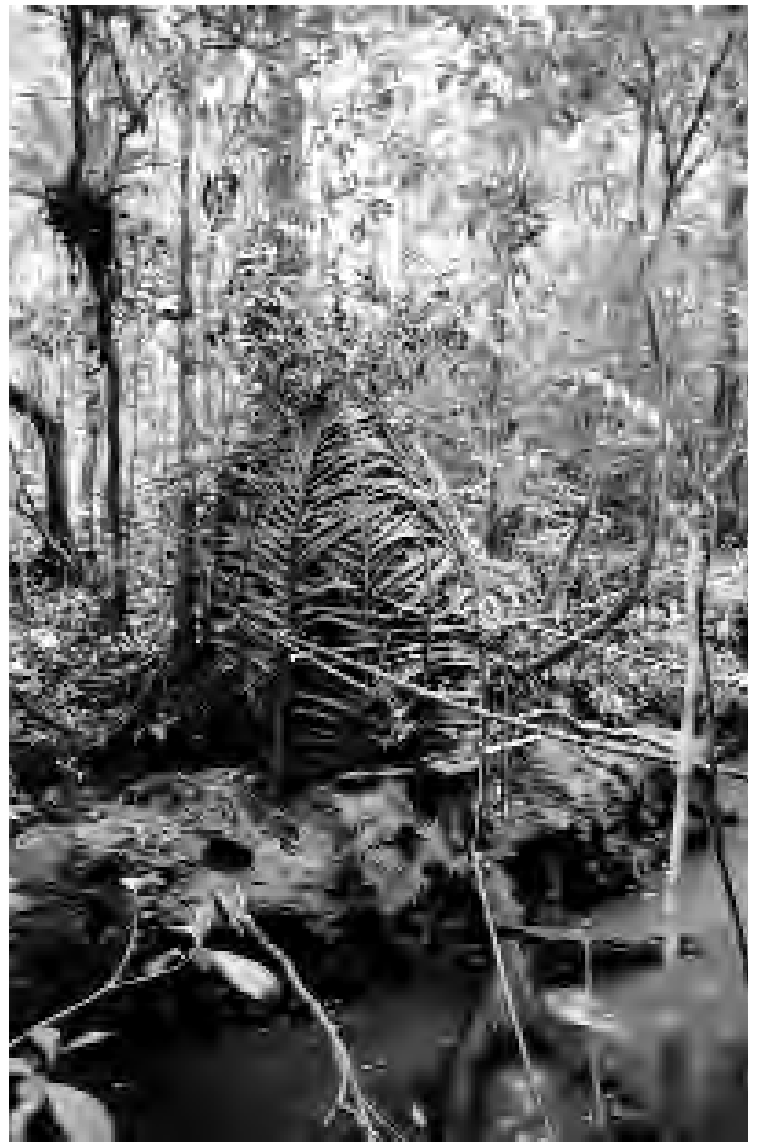

Figure 4.31 Site 27 - Tengum Lisa: bird of paradise hunting hide near waterhole in doline

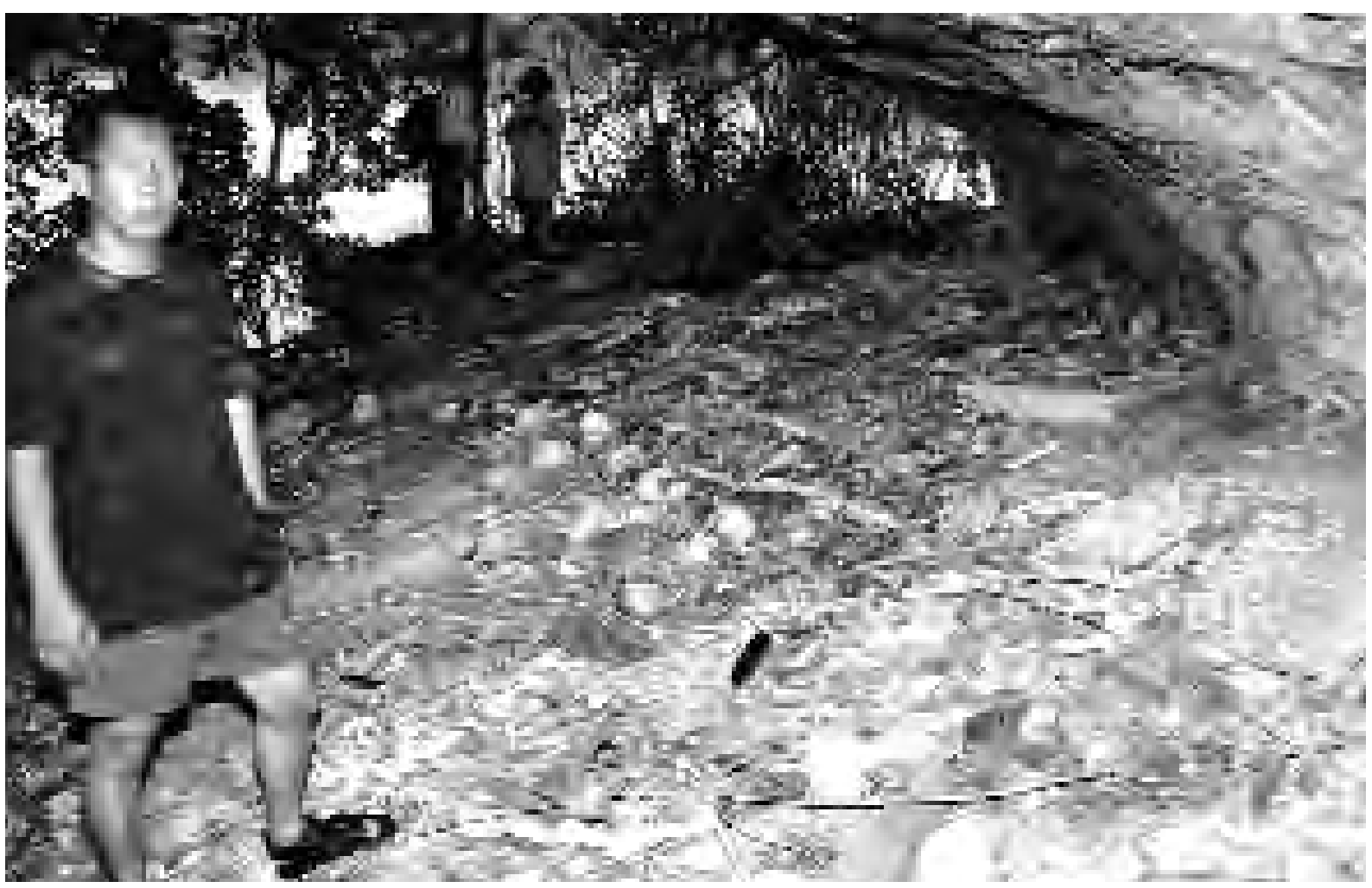

Figure 4.32 Site 28 - Silu Bata Bata: burial shelter with decayed remains of boat coffins and human skulls littering surface 


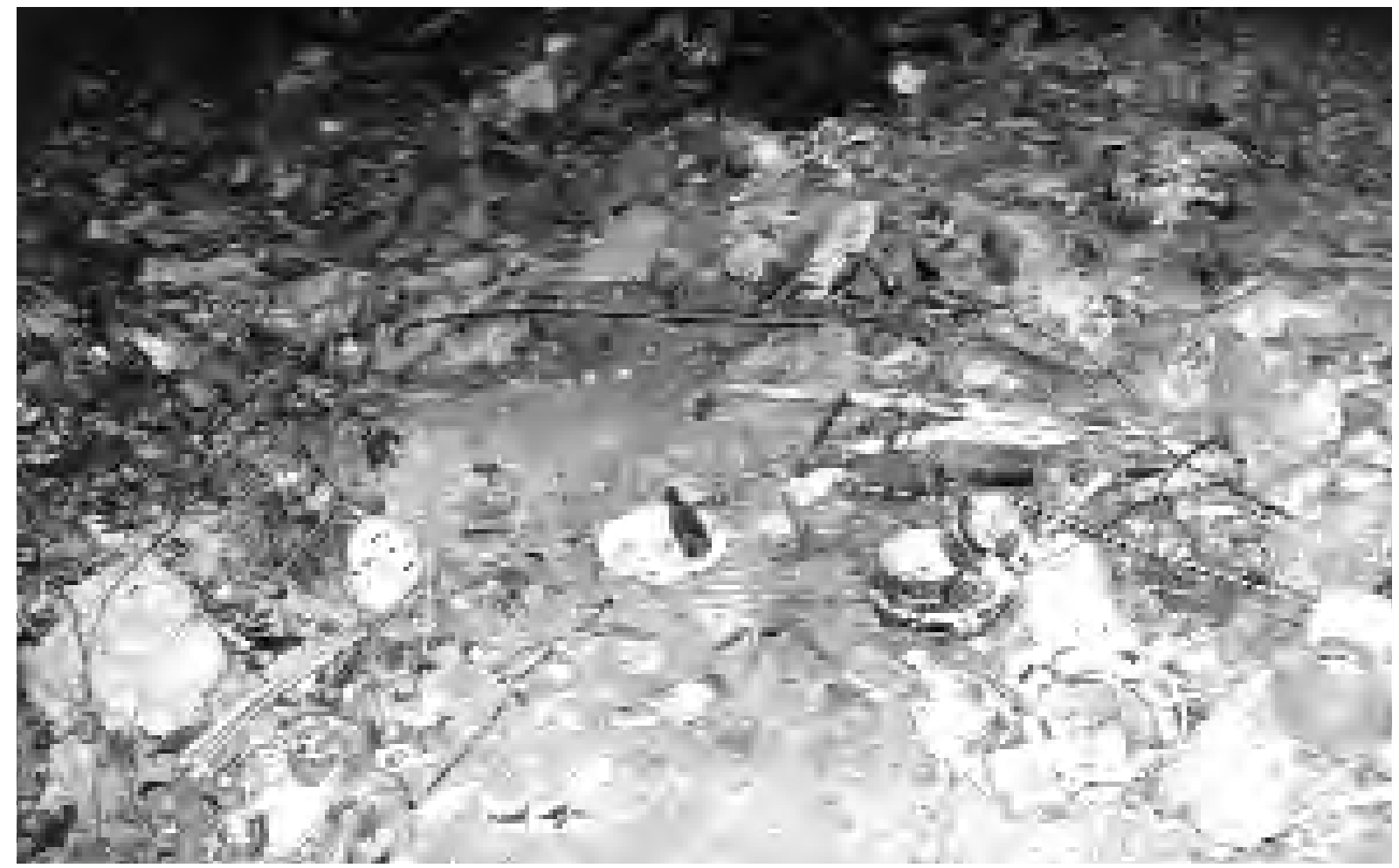

Figure 4.33 Site 28 - Silu Bata Bata: close-up of imported ceramic grave goods

ladles and plates, local earthenware pots, and pearl buttons (Fig. 4.33). Some of the burials are in wooden canoe coffins. The present inhabitants of the village said that these burials were already here when they settled the area. Only minimal limestone rubble and silts cover an otherwise stony floor indicating that the cave has no excavation potential.

\section{Site 29 - Gorangai Gua}

Wokam Island ( $\left.5^{\circ} 50.48^{\prime} \mathrm{S}, 134^{\circ} 35.64^{\prime} \mathrm{E}\right)$. A rockshelter at $100 \mathrm{~m}$ altitude, about an hour's walk from the nearest navigable sungai - Sungai Juaju (off Sungai Bauwtu) — and on Wakua village land. The name translates in Wakua as 'men who live in the forest'. The cliff face here is eight metres high, and ceiling height at the entrance is about two metres. The shelter mouth faces $220^{\circ}$ and is about $12 \mathrm{~m}$ across. The shelter goes back six metres into the cliff. The front of the cave consists of a fine loose grey sediment and is covered in dried palm leaves used for sleeping on, placed around a hearth. The back of the cave has a firmer cave earth deposit. The shelter is used as a hunting camp today but the owner did not know anything about the people who had left Geloina sp. and Terebralia sp. shells on the floor. Animal bone on the surface included the ulna of a small wallaby, of a type targeted by hunters in this area. The area of deposit immediately behind the dripline has some excavation potential. The site lies within a closed valley with a periodically flooded doline about $200 \mathrm{~m}$ to the east. We were told that this doline holds water even during dry periods.

The site area is a closed forest of medium height and the topography is more hilly than Kobroor Island. A dense canopy of Elaeocapus, Sapindaceae and Myrtaceae occurs here but the forest is open underneath with thick leaf litter. The understorey consists of scattered palms and cycads and is relatively easy to walk through.

\section{Site 30 - Djara Leang}

Wokam Island ( $\left.5^{\circ} 57.30^{\prime} \mathrm{S}, 134^{\circ} 26.00^{\prime} \mathrm{E}\right)$. A limestone cave, $24 \mathrm{~m}$ from the dripline to the back wall. The cave is close to Sungai Manumbai. The entrance faces southwest $230^{\circ}$, but the main axis of the 
cave runs southeast to northwest. The cave has a length of $24 \mathrm{~m}$ from the dripline to the back wall, and a maximum width of six metres. A talus deposit slopes gently from the dripline at the entrance into the cave for a length of $19 \mathrm{~m}$, and is covered with roof-fall and broken stalactites. The surface sediment is dark grey-brown with little cultural material evident. A few Geloina coaxans and Terebralia sp. shells, and one fragment of bone were observed, but no pottery was seen on the surface. Cracking of the surface indicates a wet-dry cycle, with the cave being regularly inundated. Andrerias Jelon, kepala desa of Wakua, said that the cave was used during World War II to store village valuables such as brass gongs and elephant ivory. It shows no sign of recent use and has little excavation potential because of regular flooding and its dark and wet environment, making it unsuitable for occupation.

\section{Site 31 - Yansen}

Wamar Island ( $\left.5^{\circ} 46.02^{\prime} \mathrm{S}, 134^{\circ} 11.63^{\prime} \mathrm{E}\right)$. This is the site of a Dutch fort on a headland of this name to the north of the Wangil midden (Site 10) (Fig. 4.34). It is identified by the local inhabitants as a Dutch fort and is probably the third such fort in Aru mentioned by Merton (1910:163) as being at Wangil, the other two being at Wokam (Site 1) and Dosi (not visited). Merton claims that these 17th century forts were abandoned because of local uprisings during the 18th century and were not re-occupied. The name is derived from the probable Dutch name of this fort, Janszoon, named after Willem Janszoon, captain of the Duyfken and first European to set foot on

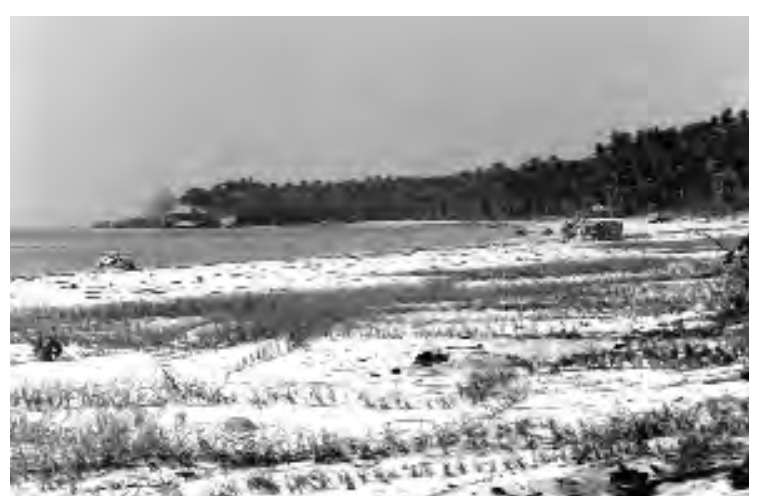

Figure 4.34 Site 31 - Yansen: view of the Yansen headland on which we located the remains of the Dutch fort. Photo taken looking north from near the Wangil midden Australia. The fort or blockhouse consists of a 15 by $10 \mathrm{~m}$ rectangular structure. Also present round the headland were partly-buried coral block wall footings about $0.5 \mathrm{~m}$ wide, the robbed remains of the enclosing wall of the fort. The headland is covered by a scatter of Chinese and Dutch trade porcelains and also some red-slipped local earthenware, as well as shell midden. Later use is shown by several dugout positions - probably Japanese gun emplacements from World War II — and two Japanese graves. The graves are made of coral blocks covered with plaster. The plaster on one had nearly all disappeared, but the other had recently had Japanese characters scratched into it. Local tradition asserts that these are Japanese war graves.

\section{Conclusions}

Our work on the islands of the northwest, closest to the edge of the continental shelf, has indicated that suitable caves and rockshelters do not exist in this part of Aru. Caves with excavation potential were only located within the interior limestone karst country, and even there they are relatively uncommon. We were lucky in choosing to excavate two sites with complementary sequences covering much of the last 30,000 years of occupation of the Aru interior.

Coastal midden sites are relatively common in some areas and have the potential to produce mid-Holocene to recent cultural sequences. This potential was not fully realized within this project because of time constraints. The main excavated midden site at Wangil (Site 10) yielded deposits dating back over 700 years in the portion which we excavated. However, the preliminary data derived from auguring of the Fany oval suggest that mid-Holocene sediments are to be found on the sandspit forming the Dobo peninsula. This spit precedes the silting up of the old valleys and 
formation of the present low-energy coastline. The midden deposits in the Fany oval are likely to be of mid-Holocene age and further study of such deposits would no doubt be productive.

The location of large, pre-1850 village sites in the extensive reef systems on the east coast of Aru suggests a much greater involvement of this area with the wider world than is commonly appreciated. At least two of the sites - Jambu Air Lama and Sirlasi (Sites 17 and 18) - appear to represent major entrepots or distribution centres for traded marine products. Ujir in the northwest of the group appears to have had a similar function, perhaps more in relation to forest products, and possibly starting somewhat earlier in the period prior to Dutch penetration of the region (see Chapter 5, this volume).

We visited two of the three historically-known Dutch forts. It is likely that further work at all three sites would reveal much about the early interaction between the indigenous Aru population and the colonial power as Aru became ever more enmeshed into the world system of trade.

\section{References}

Glover, I.G. 1979. The effects of sink action on archaeological deposits in caves: an Indonesian example. World Archaeology 10(3):302-17.

Kolff, D.H. 1840. Voyages of the Dutch Brig of War 'Dourga' through the Southern and Little Known Parts of the Moluccan Archipelago ... during the Years 1825 and 1826. London: James Madden.

Merton, H. 1910. Forschungsreise in den Sudostlichen Molukken (Aru-und Kei Inseln). Frankfurt A.M.: Senckenbergischen Naturforschenden Gesellschaft. English translation by A. and A. Veth (1998), James Cook University, Townsville.

O'Connor, S. 2003. Report of nine new painted rock art sites in East Timor in the context of the western Pacific region. Asian Perspectives 42(1):96-128.

von Rosenberg, C.B.H. 1867. Reis Naar de Zuidoostereilander Gedaan in 1865 op last der Regering van Nederlandsch-Indie. 's-Gravenhage: Martinus Nijhoff.

Spriggs, M., P. Veth, and S. O'Connor. 1998. In the footsteps of Wallace: the first two seasons of archaeological research in the Aru Islands, Maluku. Cakalele: Maluku Studies Research Journal 9(2):63-80.

Spyer, P. 2000. The Memory of Trade: Modernity's Entanglements on an Eastern Indonesian Island. Durham and London: Duke University Press.

Valentijn, F. 1862[1722]. Oud en Nieuw Ost-Indien: met Aanteekeningen, Volledige Inhoudsregisters, Chronologische Lijsten, enz. Volume III. 's-Gravenhage: H.C. Susan.

Veth, P., M. Spriggs, A. Jatmiko, and S. O'Connor. 1998. Bridging Sunda and Sahul: the archaeological significance of the Aru Islands, Maluku. Modern Quaternary Research in Southeast Asia 15:157-77.

Wright, H.R.C. 1958. The Moluccan spice monopoly, 1770-1824. Journal of the Malay Branch of the Royal Asiatic Society 31(4). 